University of Nebraska - Lincoln

DigitalCommons@University of Nebraska - Lincoln

1982

\title{
The Fayum Primate Forest Revisited
}

Thomas M. Bown

U.S. Geological Survey

Mary Kraus

University of Colorado

Scott Wing

U.S. Geological Survey

John Fleagle

State University of New York

Bruce H. Tiffney

Yale University

See next page for additional authors

Follow this and additional works at: https://digitalcommons.unl.edu/usgsstaffpub

Part of the Earth Sciences Commons

Bown, Thomas M.; Kraus, Mary; Wing, Scott; Fleagle, John; Tiffney, Bruce H.; Simons, Elwyn; and Vondra, Carl F., "The Fayum Primate Forest Revisited" (1982). USGS Staff -- Published Research. 245.

https://digitalcommons.unl.edu/usgsstaffpub/245

This Article is brought to you for free and open access by the US Geological Survey at DigitalCommons@University of Nebraska - Lincoln. It has been accepted for inclusion in USGS Staff -- Published Research by an authorized administrator of DigitalCommons@University of Nebraska - Lincoln. 
Authors

Thomas M. Bown, Mary Kraus, Scott Wing, John Fleagle, Bruce H. Tiffney, Elwyn Simons, and Carl F. Vondra 
Thomas M. Bown

U.S. Geological Survey, Denver, Colorato 80225, U.S.A.

\section{Mary J. Kraus \\ Department of Geology, \\ The Lniversity of Colorado, \\ Boulder, Colorado 80309, L.S.A.}

Scott L. Wing

U.S. Geological Survey, Menlo Park, California 94025, U.S.A.

John G. Fleagle

Health Sciences Center,

State University of New York,

Stony Brook, New York 11794,

U.S.A.

\section{Bruce H. Tiffney \\ Department of Biology and \\ Peabody Museum, Yale University, \\ New Haven, Connecticut 06520, \\ U.S.A.}

\section{Elwyn L. Simons}

Primate Center, and Departments of Anthropology and Anatomy,

Duke University, Durham,

North Carolina 27705, U.S.A.

\section{Carl F. Vondra}

Department of Earth Science, Iowa State University, Ames, Iowa 50010, U.S.A.

Received 3 April 1982 and accepted 31 May 1982

Kejwords: primate habitats, paleoenvironments, North African Oligocene, Fayum Province of Egypt,

Aegyptopithecus, Apidium.

\section{The Fayum Primate Forest Revisited}

In Oligocene times, the Fayum area of northern Egypt was a subtropical to tropical lowland coastal plain with damp soils and seasonal rainfall that supported an abundance and variety of vegetation, including lianes (large vines), tall trees, and possibly mangroves, and a large and varied vertebrate fauna. The Oligocene marine strandline was close by and principal Jebel Qatrani Formation streams were probably brackish several kilometers inland due to tidal incursions.

Sediments of the Jebel Qatrani Formation were deposited by several large meandering streams, associated with minor but sometimes extensive floodbasin ponds. These rocks provide no evidence for the former existence, in early Tertiary time, of a "Proto-Nile" River. Large accumulations of silicified fossil logs in the Jebel Qatrani Formation are autochthonous and the logs were transported only a short distance before burial. The Oligocene higher primates Argiptopithecus, Propliopithecus, Parapithecus, and Apidium lived in this paleoenvironment and postcranial remains of Aegiptopithecus and Apidium demonstrate that these animals were arboreal. This scenario for the paleoenvironment of the Fayum area in Oligocene times differs greatly from the nearly treeless, sparsely vegetated, semiarid sahélien Oligocene Fayum paleoenvironment populated by terrestrial primates that was recently proposed by Kortlandt (1980).

\section{Introduction}

In a recent paper published in this journal, Adriaan Kortlandt (1980) offered a novel interpretation for the basic adaptation and paleohabitat of the early higher primates, particularly Aegyptopithecus, Apidium, and Parapithecus. He proposed that these primates were not arboreal denizens of the forest but were all ground dwelling species living in a semiarid, almost treeless scrubland (sahélien). His basic postulates are (Kortlandt, 1980, p. 277) that: (1) the lithological characteristics of the Jebel Qatrani Formation point to a sahélien type of climate; (2) the calcified and silicified root systems in the Jebel Qatrani

Journal of Human Evolution (1982) 11, 603-632 
Formation, having diameters up to $4 \mathrm{~cm}$, suggest a sahélien type of shrub, bushland and/ or small-tree vegetation; (3) the large fossilized logs in the Jebel Qatrani Formation cannot have grown where they are found and represent driftwood from a more humid climatic belt in the south, as indicated by paleobotanical data and damage resulting from long fluvial transport; and (4) there may have been some minor patches of medium-height forest and/or woodlands in the Fayum delta, but there is no evidence of these and the tall forest in which the earliest known African primates are currently supposed to have lived probably never existed. Kortlandt believes that his interpretations of Oligocene paleoenvironments in the Fayum area support his contention that the earliest primates were ground-dwellers and that the arboreal theory of primate origins and specializations is rooted ". . . in pre- and pseudoscientific indoctrination". (Kortlandt, 1980, p. 278).

Because the Jebel Qatrani Formation and its assemblage of primates is critical to an understanding of the early evolution and habits of the oldest known higher primates, and because we believe that Kortlandt has consistently misrepresented or misinterpreted both the geologic and paleontologic evidence, we feel that a summary of current knowledge pertaining to the Jebel Qatrani Formation and its paleoenvironments is timely. Nearly all paleontologic and geologic data that bear on this problem suggest that, in Oligocene times, the Fayum area (Figure 1) was coastal and subtropical to tropical in climatic regime. The climate showed alternating wet and dry periods and may have been monsoonal, with generally moist (in some cases, forest) soils that supported a large and diverse flora and fauna. The sahélien environment imagined by Kortlandt did not exist in the Oligocene Fayum. These conclusions are consistent with, but do not prove, an arboreal habitus for Oligocene higher primates. That the Oligocene Fayum primates were probably arboreal is supported by anatomical evidence, some of which is outlined here.

In the following sections, we present a diversity of paleontologic and geologic evidence that we believe supports our interpretation of a much wetter and more forested Fayum paleonenvironment during the Oligocene. Because Kortlandt's interpretation of this paleoenvironment is based on detailed, and often trivial and/or antiquated lines of evidence, it has often been necessary to construct our replies in similar detail to answer fully the questions he raises. These replies are both geological and paleontological in content and the principal points discussed by Kortlandt are first discussed, then treated individually under the specific headings.

\section{The Geological Perspective}

Summary of Jebel Qatrani Formation sedimentology (M. J. Kraus)

Kortlandt (1980) drew upon the geologic investigations of Bowen \& Vondra (1974) to support his contention that the Fayum Oligocene paleoenvironment was relatively dry. In his summary of their interpretations, Kortland (1980, p. 280) states that the Jebel Qatrani Formation sediments were deposited (1) in ". . . a freshwater delta by a large meandering river which we may call the Proto-Nile". He further argues that lithologic features described by Bowen \& Vondra (1974), including (2) mudcracks, (3) carbonates, (4) caliches, and (5) salt crystals all indicate a yearly ". . . prolonged, very arid dry season". Kortlandt's reconstruction rests on misrepresentation of Bowen \& Vondra's descriptions as well as on misinterpretation of the geologic evidence and failure to evaluate critically the validity of some lines of primary evidence. The bases of his con- 
tentions can be refuted point by point through careful review of Bowen \& Vondra (1974), and by direct field observations made in 1980 and 1981.

(1) The Jebel Qatrani Formation consists of variegated sandstones and mudstones with minor carbonates and chert pebble conglomerates and pebbly mudstones. Abundant large and small scale cross-stratified point bar sequences and preserved channel crosssections with well developed epsilon cross-bedding [Plate 1(a)] indicate deposition by meandering streams, as observed by Vondra (1967) and Bowen \& Vondra (1974). We have examined several complete channels with epsilon cross-bedding [Plate 1(a)], no larger than $12 \mathrm{~m}$ deep and $100 \mathrm{~m}$ wide. These suggest that the Jebel Qatrani Formation was deposited by several streams, that most of these were not very large, and that they certainly cannot be compared to the recent or an ancestral Nile River. The concept of a "Proto-Nile" River is a somewhat romantic holdover from the middle nineteenth century (for example, Unger, 1859, 1866) that has been perpetuated in this century by

Figure 1. Outline map of Fayum Depression area, Western Desert of Egypt, showing localities discussed in text and in following figures. 1: American Museum of Natural History fossil vertebrate quarry A; 2: Mirage Basin, west of Garet el Gehannam; 3: Madwar el Bighal area; 4: Area of Yale Peabody Museum fossil vertebrate quarry I.

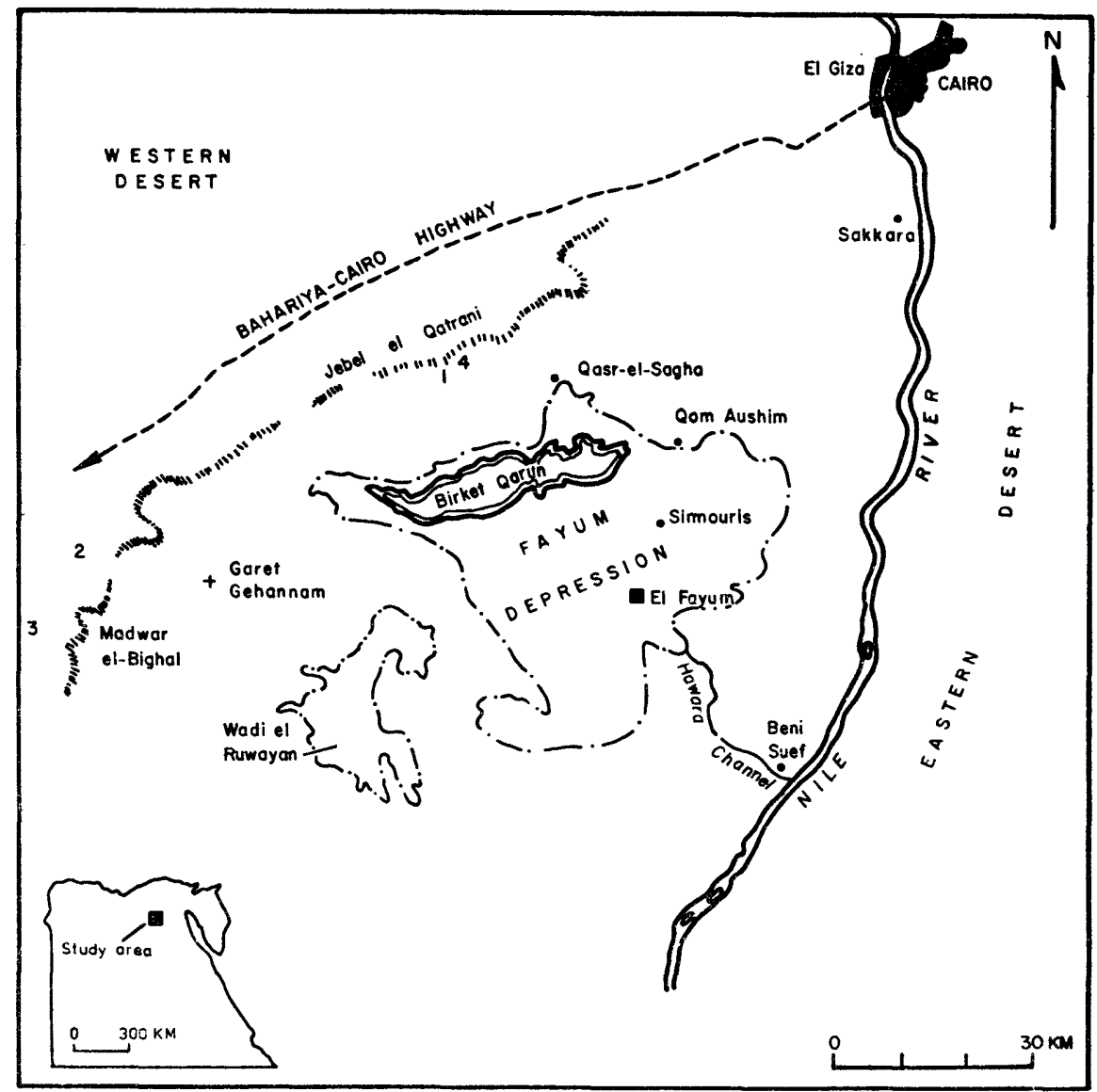


several workers (for example, Blanckenhorn, 1901; Beadnell, 1905; Ball, 1939; Said, 1962, 1981; Butzer \& Hansen, 1968; and Kortland, 1980) as an explanation for the origin of Tertiary fluvial and nearshore rocks in the Fayum and Cairo areas of northern Egypt. Though central to several of Kortlandt's hypotheses, particularly the supposed allochthonous origin of the fossil forests in the Jebel Qatrani Formation (see sections below), there is no first hand geologic evidence that indicates that Oligocene fluvial sedimentation in the north of Egypt was in any way controlled or influenced by a Nile River, ancient or modern. Said (1981) has recently restricted use of the term "Protonile" to a Quaternary stream, and no longer acknowledges any special relationship of early Tertiary rocks to a hypothetical ancestral Nile River.

(2) Mudcracks. Many of the features interpreted as deep mudcracks by Bowen (1970, figure 2E) and Bowen \& Vondra (1974), cited by Kortlandt as evidence of intense desiccation, are relict pedogenic structures. Sedimentary couplets consisting of a pale sandy unit overlying and deeply penetrating a reddish siltstone are common in the Jebel Qatrani Formation in the northern Fayum area [Plate 1(b), (c)]. The bleached tongues descend vertically and reach a maximum depth of $200 \mathrm{~cm}$ in the underlying reddish unit. The tongues are commonly as wide as $6 \mathrm{~cm}$ and taper downward. Seen in horizontal cross-section [Plate 1(c)], the bleached tongues form the outlines of and subdivide the red horizon into large polygons.

The depth of tongue penetration and the restriction of this phenomenon to white/red couplets alone contradict a mudcrack origin. On the basis of field and laboratory studies, these "cracked" zones are fragipan soil horizons (see following section). The well developed structures in the Jebel Qatrani Formation fragipans are indicative of moist, not dry or arid soil conditions.

(3) Carbonates. Carbonates form in a range of environments and under varied climatic conditions (for example, Picard \& High, 1974; Dean \& Gorham, 1975; Sellwood, 1978; James, 1979; Murphy \& Wilkinson, 1980), and in themselves are not evidence for aridity, seasonal or otherwise. Furthermore, many carbonates in the Jebel Qatrani Formation yield abundant freshwater charophytes and indicate deposition in non-saline standing water (see section on invertebrate fossils).

(4) Caliches. Bowen \& Vondra (1974, p. 131) recorded “. . . very dolomitic disrupted framework sandstones or arenaceous coarsely crystalline dolomites which range in thickness from 1 to $3 \mathrm{~m}$...", containing abundant rhizoliths (root casts) in dolomite. Bowen \& Vondra interpreted these deposits as dolomitic caliches formed by periodic aridity. Several factors cast considerable doubt on a calcrete origin for these dolomitic units.

Calcrete horizons in non-gravelly parent materials show a diagnostic developmental sequence (Gile et al., 1965, 1966). Initially, carbonate filaments and then nodules appear. More mature calcretes have abundant nodules with carbonate-filled internodular spaces (stage III of Gile et al., 1966). The horizon is "plugged" and well cemented by carbonate and oolitic or pelletal texture and locally abundant pisoliths occur (Gile et al., 1965, 1966; Hay \& Reeder, 1978). Finally, a laminar zone of nearly pure carbonate is formed (stage IV), and this overlies a nodular stage III horizon. Though data on the rates of carbonate buildup are scarce, mature calcrete development, especially in non-gravelly parent materials, is a lengthy process. Hawley et al. (1976) report that stage IV calcretes 
Plate 1. (a) Cross-section of portion of channel of meandering stream, showing epsilon point-bar sequences and probable fragipan horizons in alluvial paleosols. Lower part of Jebel Qatrani Formation, approximately $6 \mathrm{~km}$ southeast of Yale quarry I. (b) Cross-section of fragipan horizon in an alluvial paleosol in the middle part of the Jebel Qatrani Formation, approximately $1.3 \mathrm{~km}$ south-southeast of Yale quarry I. (c) Horizontal cross-section through fragipan horizon of alluvial paleosol in upper part of Jebel Qatrani Formation, about $2 \mathrm{~km}$ west of Yale quarry $\mathrm{I}$.
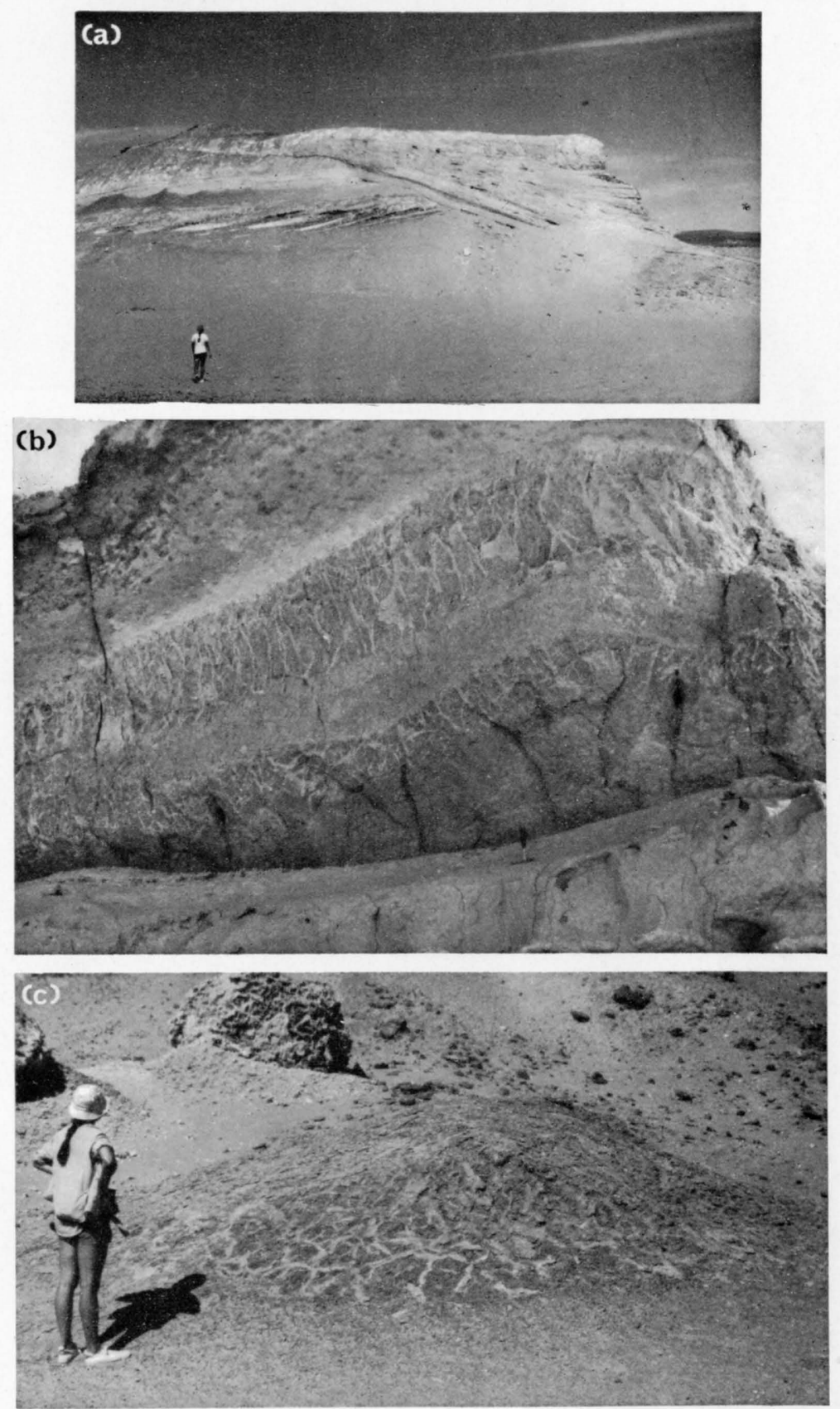
Plate 2. (a) Rhizolith mass in limonite and silica cemented sandstone from upper part of of Jebel Qatrani Formation, about $10 \mathrm{~km}$ west-northwest of Yale quarry I. (b) Silicified stump of fossil tree with roots, from lower part of Jebel Qatrani Formation, approximately $8 \mathrm{~km}$ southeast of Yale quarry I. (c) Silicified log with branches preserved; lower part of Jebel Qatrani Formation, from same area as (b).
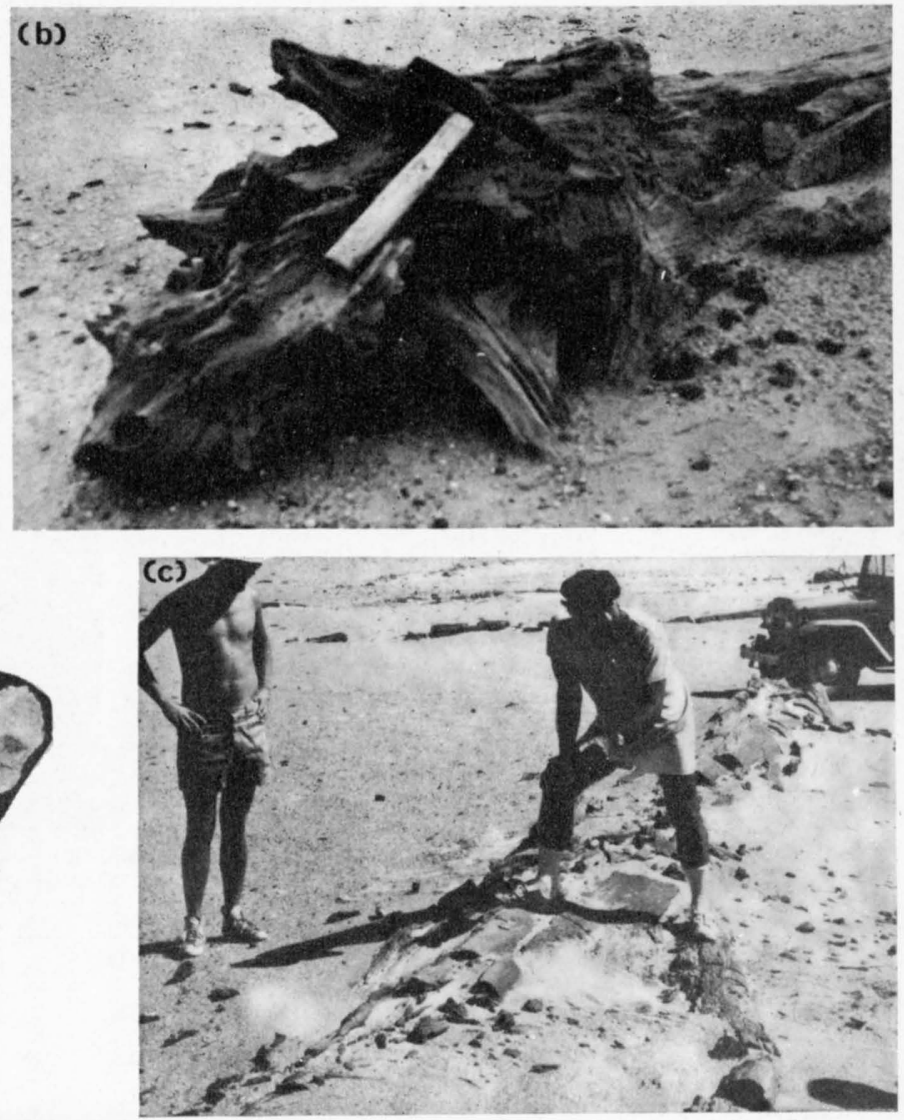

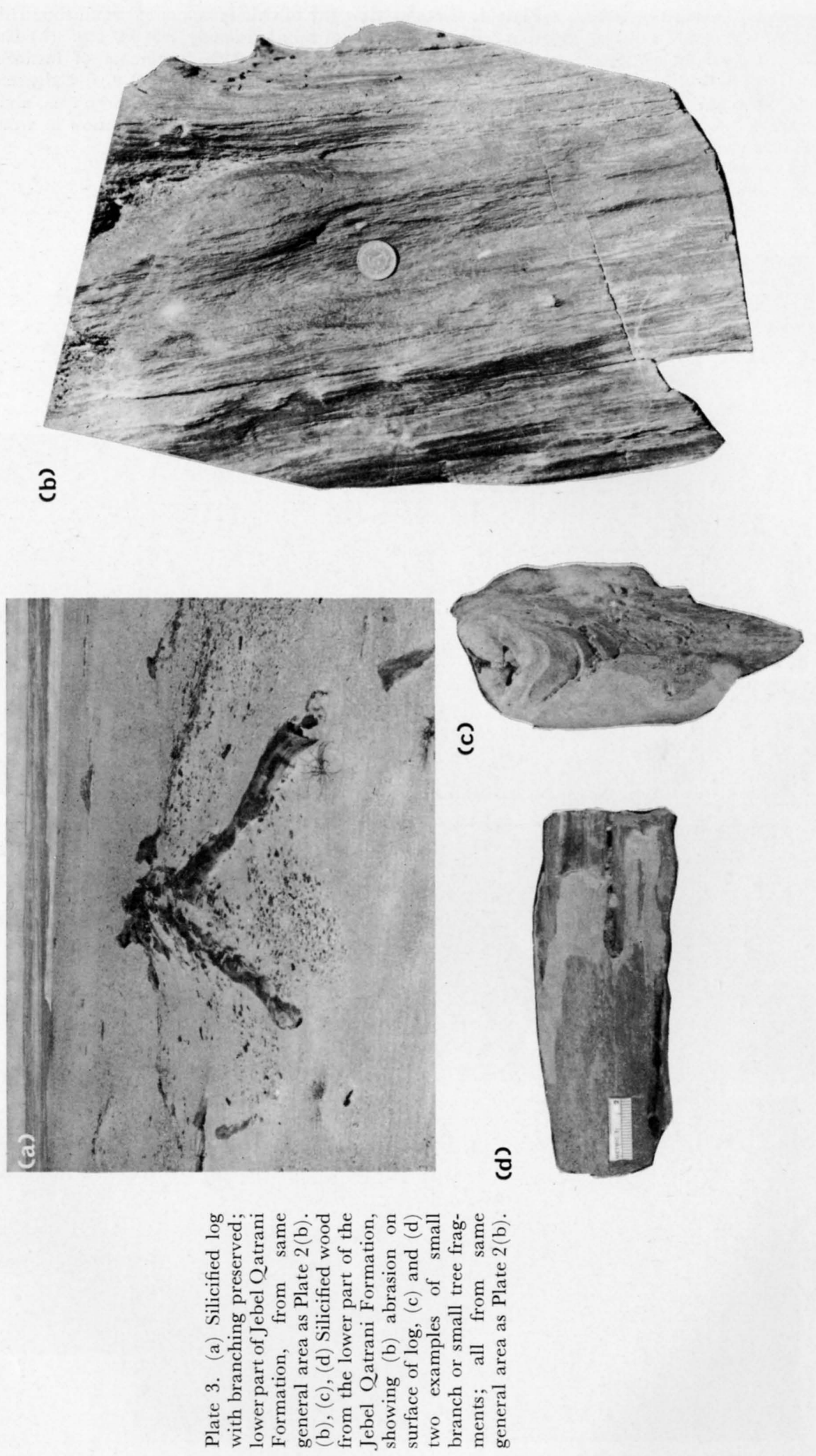
Plate 4. Lateral view (a) of calcite cemented sandstone rhizolith of root with a diameter of approximately $7 \cdot 5-9 \cdot 0 \mathrm{~cm}$. (b) Calcareous sandstone rhizoliths associated with fragments of fossilized wood (a) -(b) from same general area as Plate 2(b). (c) Calcareous sandstone rhizolith of stump and root system of a large tree, about $2.0 \mathrm{~m}$ in diameter, from base of Jebel Qatrani Formation in western part of Mirage Basin (see Figure 1).
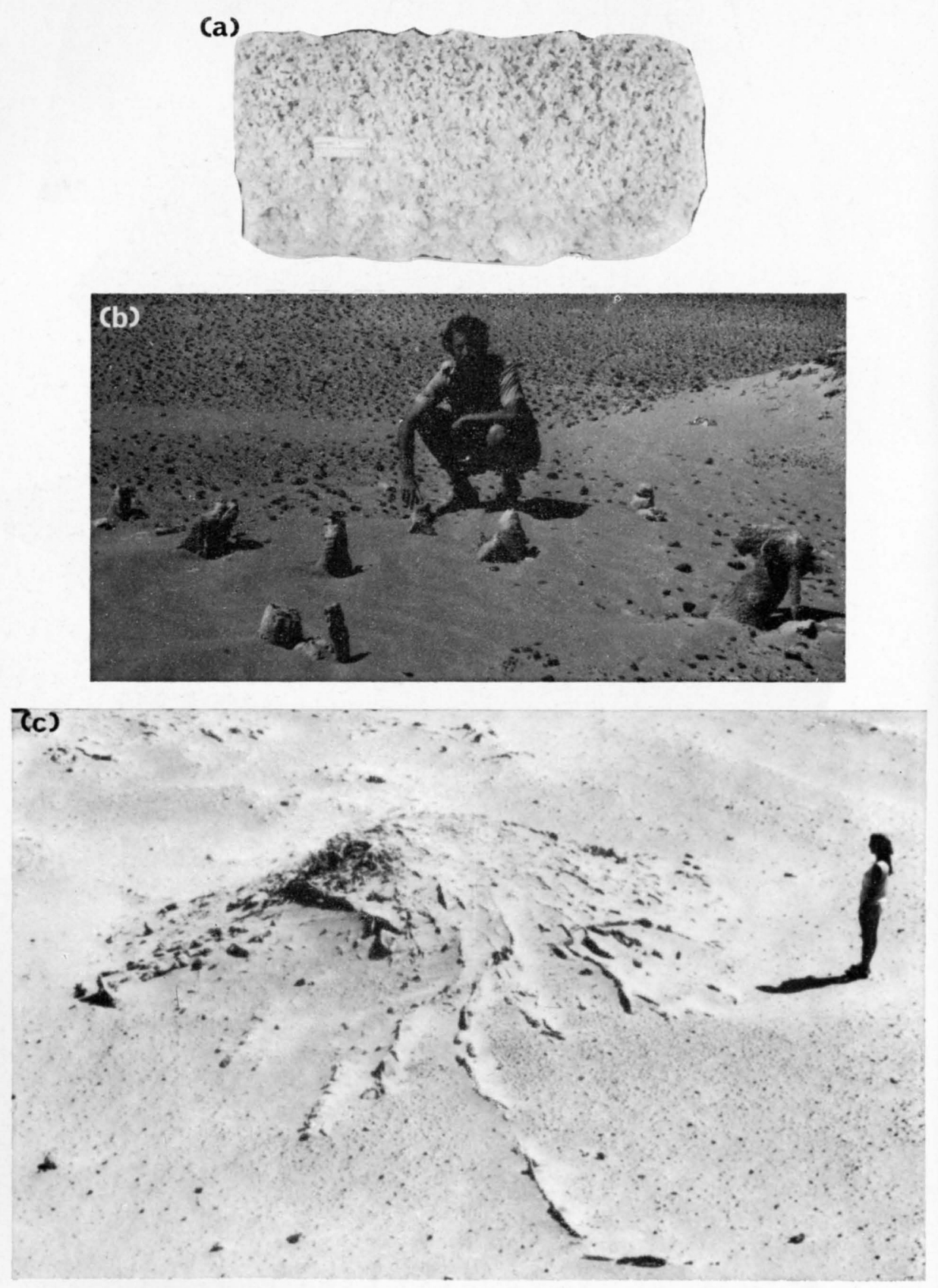
Plate 5. (a) "Forest" of small calcareous sandstone rhizoliths exposed on deflated surface in upper part of Jebel Qatrani Formation about $1.8 \mathrm{~km}$ east-northeast of Yale quarry I. (b) Dense calcareous sandstone rhizolith mat in $20 \mathrm{~m}$ thick rhizolith sequence in basal part of Jebel Qatrani Formation on east side of Mirage Basin. Many of the rhizoliths at this locality are probably of mangroves. (c) Nests (domichnia) and filled entrance gallery of an unknown invertebrate (probably a social insect), from lower part of Jebel Qatrani Formation, about $8.5 \mathrm{~km}$ southwest of Yale Quarry I. Note burrows and other bioturbation in lower part of unit.
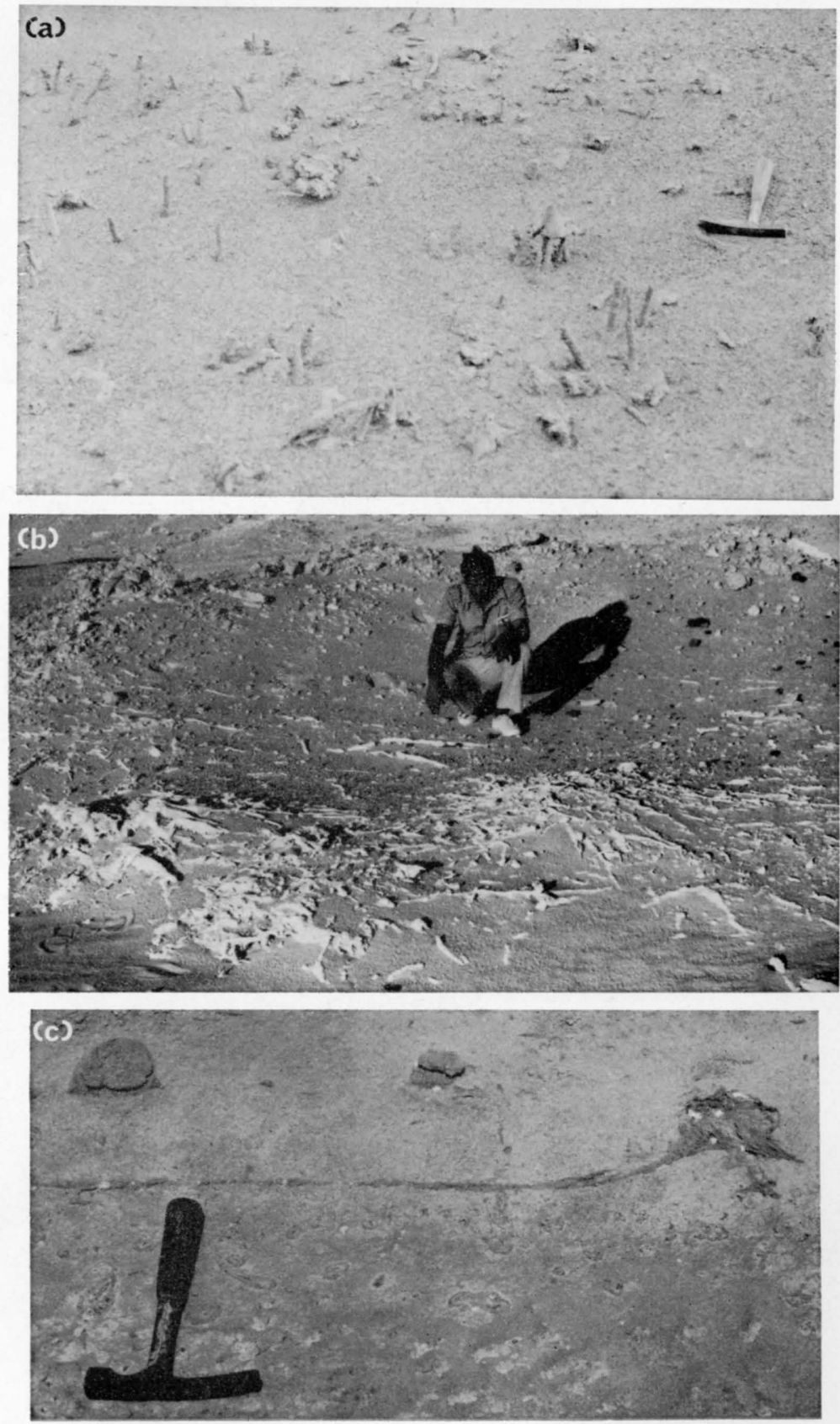
Plate 6. Epipremnum species. (a) Whole infructesence showing arrangement of berries on the fruiting axis, scale in $\mathrm{cm}$. (b), (c) Closeup photographs of infructesence surface, showing several eroded berries. Each berry is defined by a thin line about its perimeter and contains four seeds of which two are visible in any one section. (d) Polished cross-section of infructescence showing individual fruits with seeds (black inclusions). Scale in $\mathrm{mm}$.
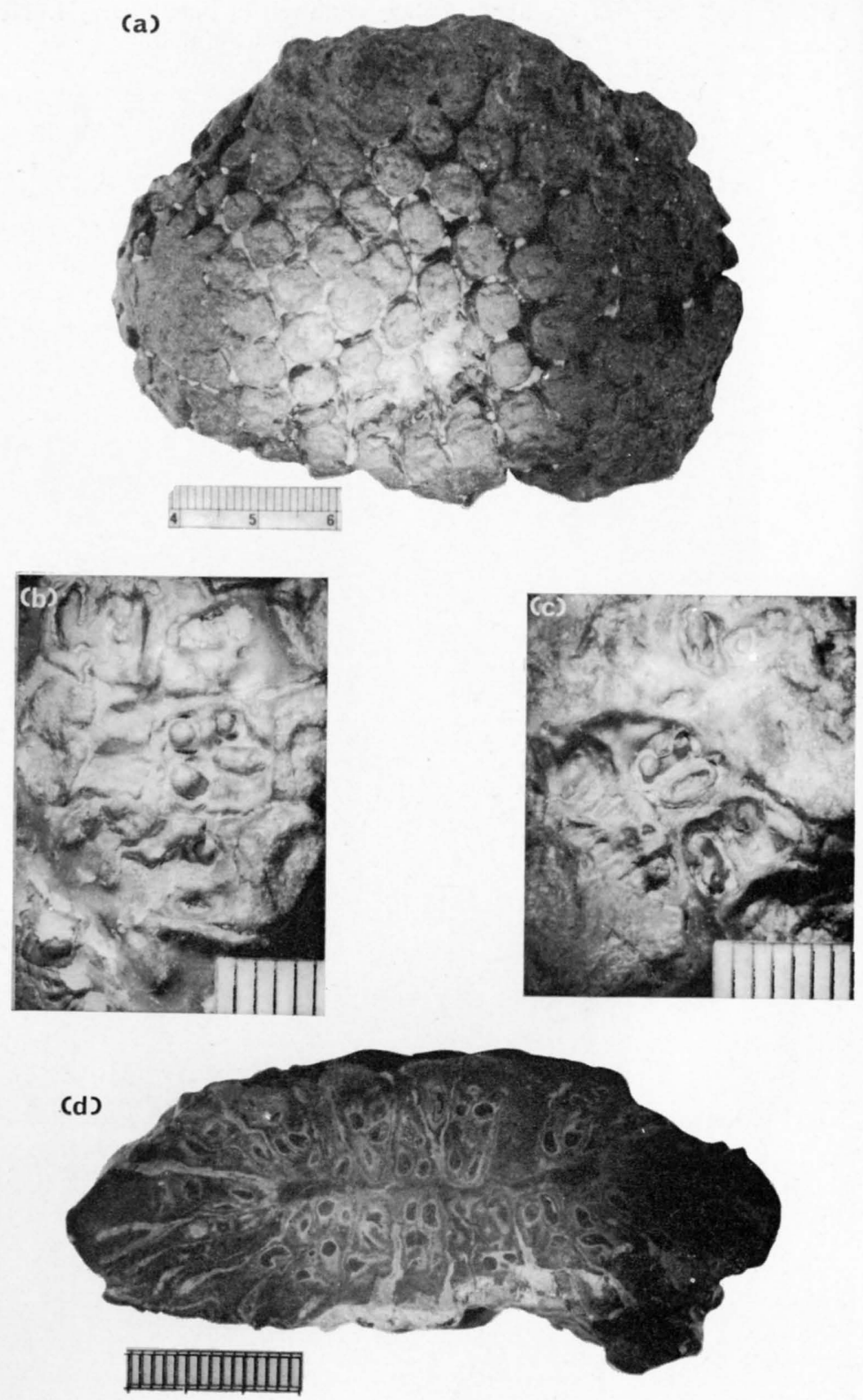

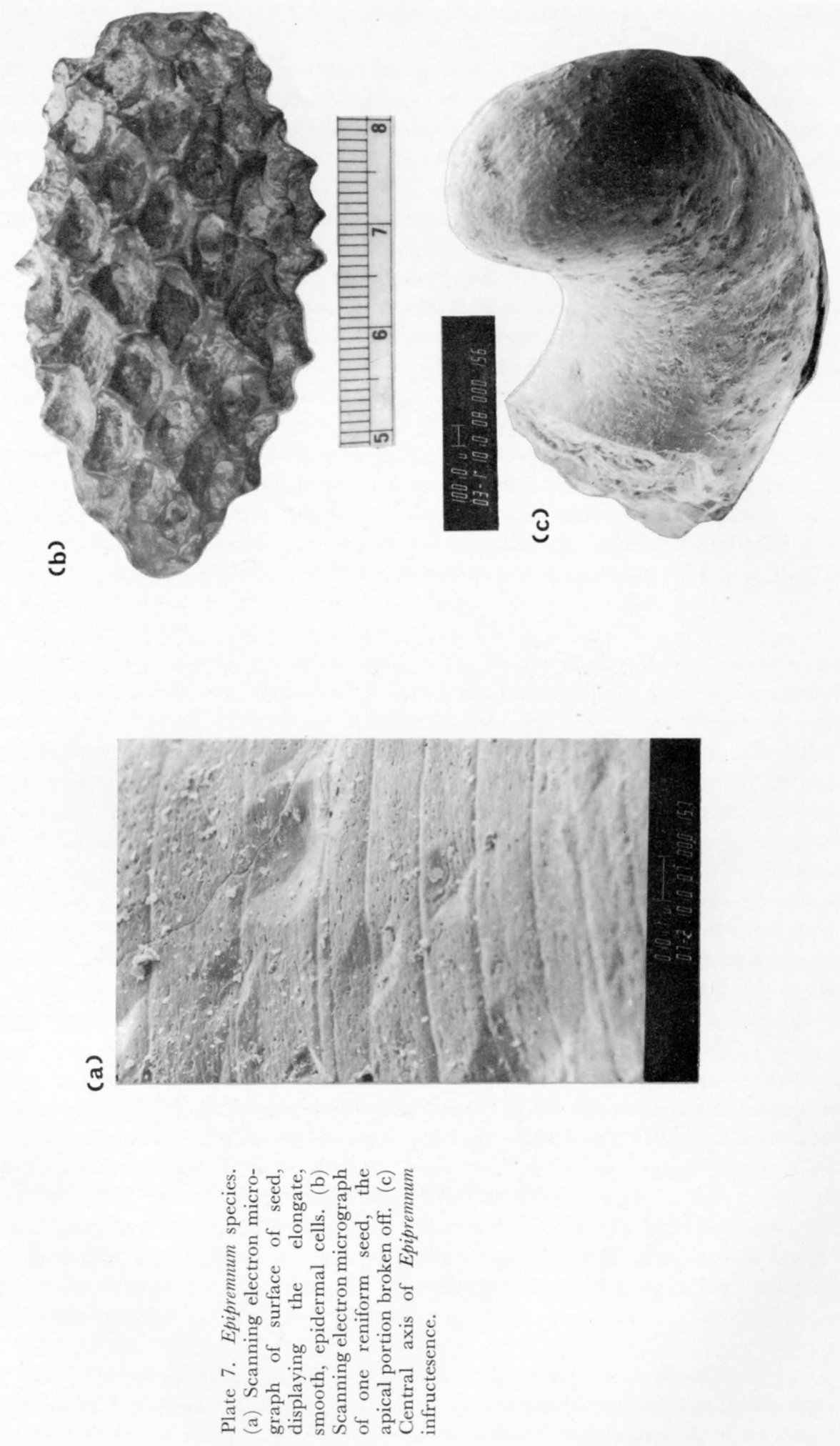
of the Jornada surface in Nex Mexico required at least 100,000 years to form. Ruellan (1967) described a sequence in the Basse Moulouya of Morocco in which the thick calcrete crusts there required several hundreds of thousands of years to form. A similar time framework for the formation of mature calcretes is confirmed by Goudie (1976, p. 90, and table 25), and Gile et al. (1981).

The horizons interpreted as calcretes by Bowen \& Vondra (1974) are thoroughly cemented zones that, if calcrete in origin, would suggest a relatively mature stage. However, with the exception of the disrupted framework of the dolomitic sandstones, those authors described none of the other textures typical of stages III or IV, nor are such textures seen either in the field or in thin section. Because of the lack of any horizons showing intermediate stages of calcrete development and because sedimentologic evidence shows that the coastal Fayum aggradational environment was unlikely to have been subject to depositional stasis for long enough periods to develop mature calcretes of the exceptional thicknesses (up to $3 \mathrm{~m}$ ) reported by Bowen \& Vondra, it is extremely unlikely that dolomites in the Jebel Qatrani Formation are calcrete in origin. Moreover, most of these dolomites contain freshwater charophytes suggesting floodplain pond origins. Absence of calcrete development is consistent with the relatively wet soils that are indicated by studies of Jebel Qatrani Formation paleopedology (see following section).

(5) Salt crystals. Saline crystals or crystal casts or molds are known from both modern and ancient sediments that were deposited in arid environments (for example, Kinsman, 1969; Surdam \& Wolf bauer, 1975; Boyer, 1981). Halite crystals were recorded by Bowen \& Vondra (1974) in the Jebel Qatrani Formation and are included in Kortlandt's (1980) list of aridity indicators. Bowen \& Vondra (1974, p. 125), however, stated that the salt crystals occur ". . . encrusted on exposed surfaces . . .", a significant point that was neglected by Kortlandt. I have observed halite crystals lining fractures in surficial weathered mudstones and shales, as well as coatings on the surfaces of exposed mudstones. They are not common and no halite crystals, pseudomorphs after halite, or casts of halite crystals have been found within any Jebel Qatrani rocks examined in the field or laboratory in thin section. The restriction of halite to fractures and as coatings on weathered rocks indicates a very late diagenetic rather than penecontemporaneous origin, probably in the modern arid climatic cycle.

(6) Conclusion. Careful re-examination of Said (1962), Vondra (1967), Bowen \& Vondra (1974), and others, as well as current geologic research in the Fayum area demonstrate that the Oligocene paleoenvironment reconstructed by Kortlandt (1980) is untenable from a strictly sedimentological point of view. Kortlandt's belief in a large "Proto-Nile" River is not founded on sound geologic and sedimentologic evidence, but on casual observations of earlier workers that were cited uncritically. The lithologic argument for a sahélien climate in Jebel Qatrani times evaporates because of its reliance on Kortlandt's misinterpretation of geologic data, his use of undiagnostic criteria, and his uncritical acceptance of the conclusions of earlier workers.

Summary of Jebel Qatrani Formation paleopedology (T. M. Bown and M. J. Kraus) Though studies of paleosols in the Jebel Qatrani Formation were not available when Kortlandt completed his study, paleosols are of paramount importance in a thorough 
paleoclimatic study of the Oligocene deposits of the Fayum area. As was shown above, the Jebel Qatrani Formation is exclusively fluvial in origin and was deposited by principally meandering streams on a lowland coastal plain. Overbank (floodplain) deposits of the Jebel Qatrani Formation are dominated by silt and fine sand, but silty clays, thin freshwater limestones and dolomites, carbonaceous shales, and very thin low grade coals occur in some local sections. Nearly all of the clastic overbank and channel deposits show considerable evidence of postdepositional pedogenic modifications, including numerous rhizoliths, invertebrate burrows, nests, and other lebensspuren (Bown, in press), iron and clay translocation, albic and spodic horizon differentiation, iron and manganese sesquioxide glaebules, and gley mottles.

The Jebel Qatrani Formation is a stacked sequence of superposed alluvial paleosols, much like the lower Eocene Willwood Formation of northwest Wyoming (Bown, 1979; Bown \& Kraus, 1981), but with somewhat coarser alluvial parent materials and, henceforth, somewhat differing soil types. Many, if not most, of the Jebel Qatrani Formation soils were very moist and formed on floodplains that frequently were inundated by waters from overbank depositional events and were periodically covered by broad areas of standing water. Similar depositional regimes are well known for other alluvial basins in tropical and subtropical areas and in which water is, at least for some part of the year, abundant (for example, Richards, 1966; Goulding, 1980). Thorough gley mottling of the solum (for example, McKeague, 1965; Freytet, 1971; Moore, 1974), and the presence of carbonaceous shales and mudstones indicate moist soils and poor drainage. Evidence of standing water on the floodplain is given by shallow freshwater charophytic dolomitic marls and extensive tabular deposits of limonitic sand and silt, in some cases "bog iron ore", which preserve masses of indurated rhizoliths (Bown, in press). See Plate 2(a). Furthermore, as demonstrated by Buol \& Yesilsoy (1964) and Buol (1965), translocation of free iron sesquioxides is a geochemical and mechanical process inhibited by very dry or arid climates.

Certain spodic Jebel Qatrani Formation paleosols have developed thick fragipan horizons [Plate 1(a), (b)]. Fragipans are subsurface pedogenic horizons characterized by high bulk density, an upper zone eluviated of free $\mathrm{Al}, \mathrm{Fe}, \mathrm{Mn}$, and silicate clays, a lower zone enriched in these materials, and division of the lower zone into large polygons by tongues of the upper zone (Daniels et al., 1966; Grossman \& Carlisle, 1969; Soil Survey Staff, 1975). Though modern fragipans develop on many parent materials and are associated with several of the great soil groups, they are restricted in their climatic range. Grossman \& Carlisle (1969) show that fragipan soils in the United States occur most commonly in humid areas with hardwood or coniferous vegetation. Moreover, strongly developed polygonal structure like that seen in Fayum paleosol fragipans, generally forms under moderately to poorly drained soil conditions (Daniels et al., 1966). Large prisms, typical of Jebel Qatrani Formation fragipans, indicate seasonal precipitation, but with short or mild dry periods (Soil Survey Staff, 1975).

All of the paleosol evidence, therefore, directly contradicts the contention that the Jebel Qatrani Formation was deposited in a sahélien type of environment, typified by low rainfall and prolonged periods of drought. Rather, these paleosols suggest that the environment was characterized by abundant rainfall and both locally and periodically high water tables. Though iron translocation and development of gleyed spodic horizons indicate that rainfall was probably spaced, the paucity of calcrete glaebules and absence of more mature calcretes (see preceding section), relatively thorough reduction and 
removal of iron compounds by extensive gleying in many spodic horizons, accumulations of "bog iron ore" and carbonaceous shale, and development of thin, tabular floodplain freshwater carbonates suggest that the overall soil environments of the Jebel Qatrani Formation were wetter than those of the subtropical, possibly monsoonal, Willwood Formation paleosols from the early Eocene of Wyoming (Bown \& Kraus, 1981).

Origin of the Jebel Qatrani Formation Fossil Forest (T. M. Bown, M. J. Kraus, S. L. Wing, B. H. Tiffney and C. F. Vondra)

Much of Kortlandt's assertion that the Jebel Qatrani Formation was deposited in a sahélien environment is founded on his conclusion that the abundant silicified wood there was derived from other, wetter, more tropical environments (principally in the now Sudanese Republic), and was transported to the Fayum area by rafting on the ancestral Nile River ("Proto-Nile"). During this transport they were, according to Kortlandt, ". . . broken to pieces when, after tropical rainstorms, they were swept over cataracts and waterfalls. Their branches and roots were nearly all broken off, and the smaller and medium-sized tree specimens were destroyed on their long journeys to the delta. Thus the forest in which the Fayum primates are currently supposed to have lived probably never existed"'. (Kortlandt, 1980, p. 284.) To contradict the observations of other workers (for example, Schweinfurth, 1882; Zittel, 1883; Blanckenhorn, 1900; Vondra, 1967; Bowen, 1970, 1971; Bowen \& Vondra, 1974) that the woods were derived from in situ gallery-like forests along Jebel Qatrani streams, Kortlandt drew on several lines of dated evidence and speculation, as well as his own assumptions regarding Fayum Oligocene paleoenvironments. The most important of these items are discussed separately. (1) The logs are largely of species indicative of a tropical rain forest (dominance of woods without growth rings in the flora) and therefore cannot have grown in a sahélien environment. (2) If the trees had grown and been fossilized where or near where they are now found, they would have roots and branches more or less intact. (3) There is a ". . remarkable gap between, on the one hand, the fossilized roots in situ not thicker than $4 \mathrm{~cm}$, which indicates that there were no real trees at all growing in the area, and, on the other hand, the large abraded pieces of trunk (15 to $200 \mathrm{~cm}$ thick!) . . " (Kortlandt, 1980, p. 284.) (4) "Signs of decay indicate that the logs had been lying in the water for a long time before running aground and being covered with sand". (Kortlandt, 1980, p. 286.)

(5) Specimens of logs with well-marked growth rings ". . . constituted only about four specimens out of the collected total of 273 identified wood specimens from Jebel el Qatrani and Jebel Ahmar". The specimens with no growth rings, in Kortlandt's view, are from areas of the tropical rain forest belt (that is, from the upper drainage of the "Proto-Nile"), whereas those with growth rings are from an area ". . . with a seasonal climate, i.e., the river delta" (Kraüsel, 1939, cited in Kortlandt, 1980, p. 286). By Kortlandt's reasoning, the very few logs with growth rings lived in the Fayum area in Oligocene times; those without them are allochthons and support his idea that the Jebel Qatrani Formation depositional lithotope was an "... almost treeless landscape". (Kortlandt, 1980, p. 286.)

Field studies in 1980 and 1981 indicate that most of the fossil wood in the lower part of the Jebel Qatrani Formation was deposited on gravel and coarse sand point bars in several distinct meandering streams, approximately bracketed by the 25-125 m levels of the formation. The wood does not occur at one or several specific horizons; rather, its expression as "the lower fossil wood zone" is due to the geomorphic expression of the exposures as a series of stacked cuestas with long, areally extensive dip slopes, several of 
which, at different levels in the lower part of the formation, are developed on these friable bar deposits which contain fossil logs. As observed above, there is absolutely no evidence that the logs were deposited by a single stream of any size and the Jebel Qatrani sediments are in no way deltaic in origin. Rather, sedimentologic evidence shows that the large trees grew along these streams and/or the gravel bars and adjacent floodplains. After falling, some of the trees may have been transported short distances before running aground on bars or stream margins when they were then covered with sand and gravel. The preferred alignment of many of the fossil logs certainly indicates movement of them by running water. Concerning Kortlandt's other lines of speculation, we offer several observations.

(1) Tropical woods. We agree that the woods from the Jebel Qatrani Formation are probably of species that grew in a wet tropical climate and cannot have grown in a sahélien type of environment. We disagree that the woods were transported any appreciable distance for evidentiary reasons discussed in points (2)-(5) below. The significance of the Jebel Qatrani floras is treated in a separate section.

(2) Roots and branches. Roots and branches on fossil logs in the Jebel Qatrani Formation, though not common, do occur [Plate 2(b), (c); Plate 3(a)]. The damaged state of the fossil logs, with only stubs of roots and/or branches occasionally intact, is the normal state of preservation of stream transported logs and does not require any special explanation, such as long distance transport. Only very rarely are trees buried in situ; minimal abrasion readily removes branches and bark, and the fossil logs of the Fayum area are characteristically found in stream gravels and coarse sand deposited by flowing water. Nonetheless, it is interesting that Kraüsel (1939) does report at least one specimen with bark in his collection (Sterculioxylon giarabubense Chiarugi, Kraüsel, 1939, p. 91). Much of the surface abrasion on the fossil logs (Plate $3(b)$ is almost certainly the result of wind abrasion by blowing sand during probably thousands of years exposure above ground in the present day arid cycle. Rolling over some of the logs reveals a siliceous limonitic rind of what appears to be poorly preserved bark on the under surfaces. In fact, then, the presence of some logs with branches and stubby remains of roots, as well as the probable preservation of bark in some specimens argues against long distance transport.

Moreover, the rooting systems of many tropical trees in reasonably moist environments are often concentrated near the more nutrient-rich surface of the soil, with only small roots actually penetrating to any depth (for a diagram, see Longman \& Jeník, 1974, figure 4.4). This shallowness increases the likelihood that large roots will decompose rapidly, either because they are pulled out of the soil when the tree falls, or due to the increased availability of the in situ roots to the highly active decomposers (including the soil meiofauna) of a warm climate. Nonetheless, root rhizoliths of tree-sized plants are locally common (see following section).

(3) Small logs. Kortlandt (1980, p. 201) comments on the ". . total absence of . . any small logs (thinner than $15 \mathrm{~cm}$ )..." This is false. In the very limited collection of Jebel Qatrani Formation woods in the Peabody Museum at Yale University (five specimens) is one piece of 5-6 cm diameter. To find wood of this size in so small a sample suggests that it is not uncommon, a fact that is reinforced by first hand field observations [Plate $3(\mathrm{c})$, (d)]. Additionally, Kraüsel (1939, p. 58) reported at least one specimen in which apparently only one year's growth was present ("Acacioxylon" vegae Schenk). 
(4) Decay of logs. From our observations, very few of the logs or wood fragments show any signs of decay before fossilization. This suggests fairly rapid burial of the logs after they fell. In any case, rot would not be evidence of long distance transport. It would only indicate that the wood was in water or wet sediment for a period long enough to initiate decay.

(5) Growth rings. Kortlandt presumably based his statement of ". . . an absence of growth rings ..." in wood from the Jebel Qatrani Formation on Kraüsel \& Stromer's (1924) and Kraüsel's (1939) summaries of the Oligocene woods of northern Egypt. Rereading these articles reveals that, though only four of the Jebel Qatrani wood taxa have distinct growth rings, nine have indistinct growth rings, two have very indistinct growth rings, and only two have no growth rings (Tables 1 and 2). In Table 1 are listed only woods from the Oligocene of the Fayum; Table 2 lists additional woods from extra-Fayum Oligocene sediments.* Kortlandt regards the presence or absence of growth rings as indicative of the plants in question having grown under two distinctly different climatic regimes; no growth rings in the humid tropical south (this wood, in his view, was transported northward by the "Proto-Nile"), and growth rings in wood from his postulated semiarid northern sahélien in the Fayum.

Actually, our recent observations in the field show that most woods in the Jebel Qatrani Formation do not have very well developed growth rings, in contrast to what might be suggested by reading Kraüsel (1939). Nevertheless, various species have different genetic capacities for seasonal growth, and individual trees, as well as species, are influenced by varying edaphic and microclimatic factors. Together, these endogenous and exogenous influences can produce a variety of seasonal and aseasonal growth responses in trees from a single geographic and climatic region (see, for example, Tomlinson \& Craighead, 1972). It is not at all unlikely that all of the woods of the Fayum region could be derived from members of a single plant community. As observed above, sedimentologic evidence argues strongly against any long distance transport of the logs. This conclusion is further supported by evidence of large rhizoliths in the Jebel Qatrani Formation (following section) and by the geographic affinities of the Fayum flora (see Paleobotany section).

Rhizoliths in the Jebel Qatrani Formation (T. M. Bown, M. J. Kraus, S. L. Wing, and B. H. Tiffney)

The alleged ". . . total absence of . . any large root systems (having roots thicker than $4 \mathrm{~cm})$..." is taken by Kortlandt $(1980$, p. 287) to imply the absence of large trees in the Fayum area during deposition of the Jebel Qatrani Formation. Kortlandt (1980, p. 280) observes: ". . . the widespread presence of thinly $(1-2 \mathrm{~mm})$ laminated clay beds indicates

\footnotetext{
* Kraüsel (1939) is unclear as to the provenance of two of these species. In each case, he lists a different place of collection in the summary table $(1939$, p. 118) than he does in the list of specimens accompanying the species description of each wood. We take the latter citation as perhaps being the more accurate, as it also includes collection numbers. These cases are: (1) ?Leguminoxylon sp. is described as coming from the Jebel Qatrani beds $(1939$, p. 59), but is listed (1939, p. 118) as from the Gebel Ahmar beds. (2) Gynotrochoxylon africanum is described as found at Dime on the surface, and Kraüsel suggests it slipped from the Jebel Qatrani beds (1939, p. 100); however, it is later given as coming from the Gebel Ahmar beds (1939, p. 118).
} 
612

要

T. M. BOWN $E T A L^{\circ}$

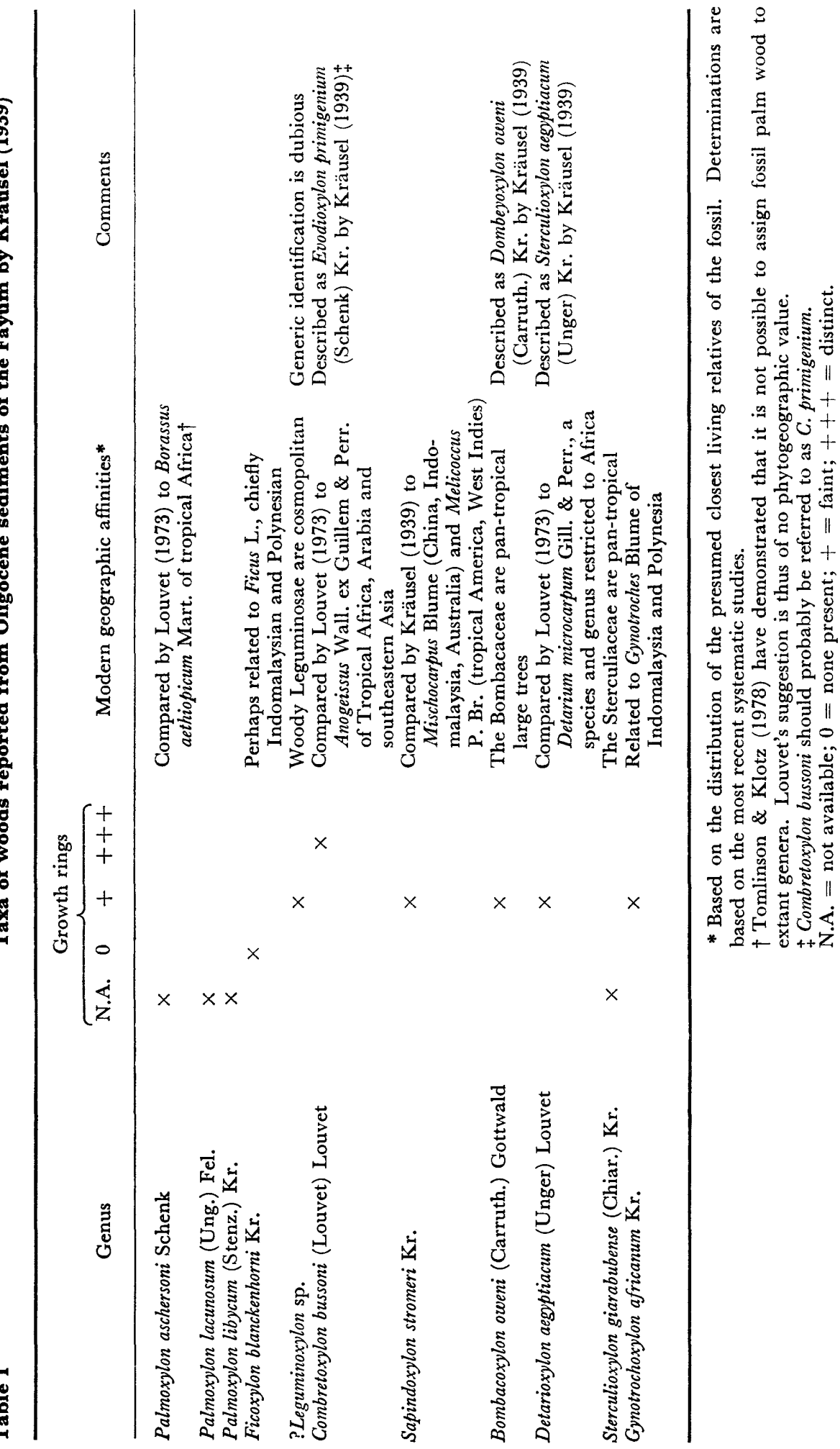




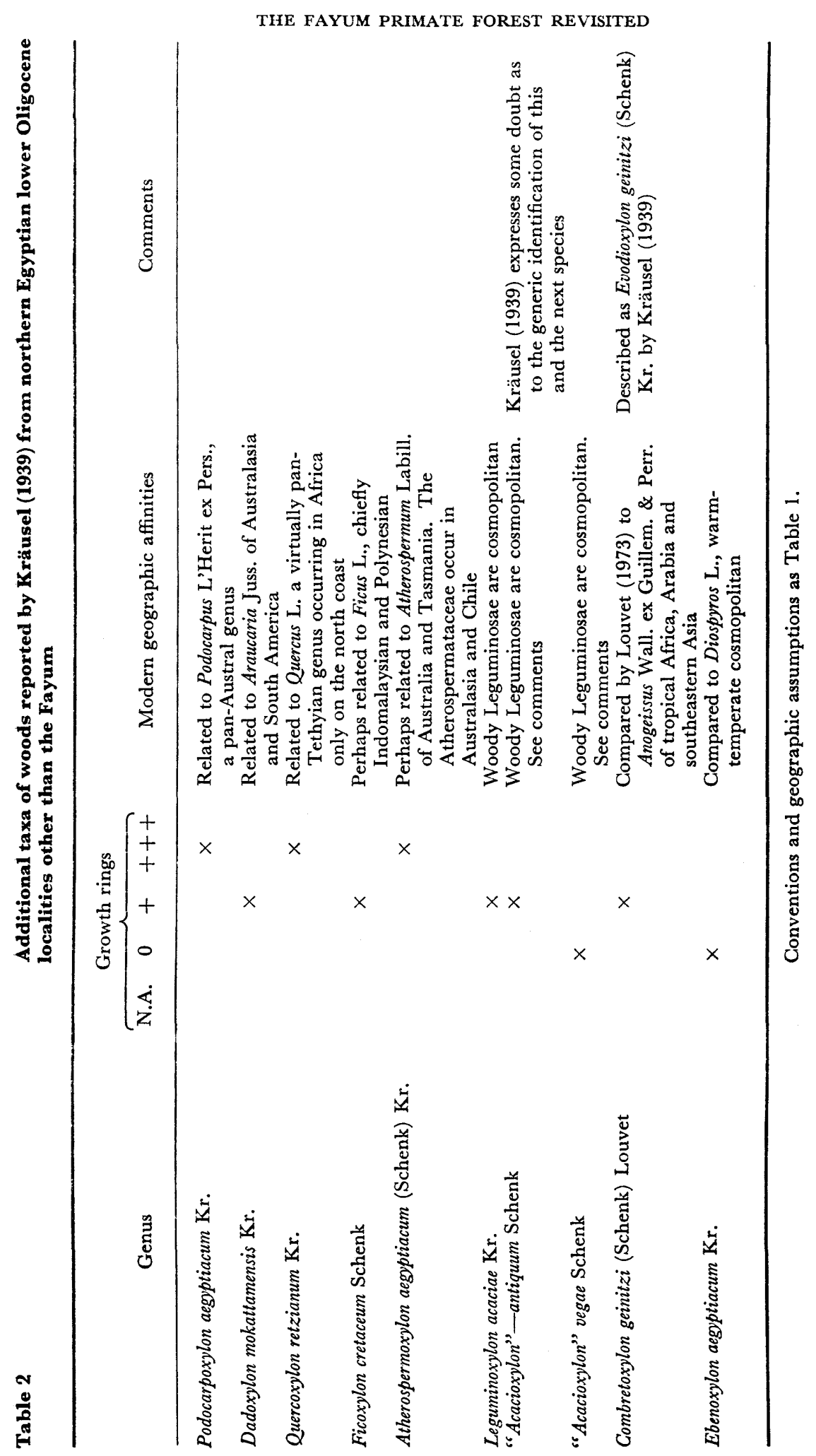

613 
that, at many places, there was very little vegetation. Otherwise, the action of roots and subterranean animals would have blotted out the lamination".

Fossil roots, or rhizoliths (for example, Klappa, 1980) are rarely to be commonly found in fluvial deposits around the world. Their preservation or absence is dependent on a number of factors, paramount of which are diagenetic alteration and proper geochemical conditions in ancient soils, but they are not always common in sequences with well preserved leaves or wood (for example, Wing, 1980; Bown \& Kraus, 1981). Absence of rhizoliths clearly does not imply absence or even sparsity of vegetation as Kortlandt believes, even though it is obvious that little vegetation would result in relatively few rhizoliths.

Sediment casts of root systems of a variety of plants, including large trees, are actually quite common in the lower part of the Jebel Qatrani Formation (Bown, in press), though their preservation seems to have been favored in some areas and not in others, possibly in response to factors discussed in the above paragraph. The largest area of fossil logs on the lower cuesta of the Jebel Qatrani Formation, about 6.5 km east of American Museum quarry A, contains numerous sandstone rhizoliths [Plate 4(c)], and specimens of these exceeding $8 \mathrm{~cm}$ in diameter are not uncommon [Plate 4(a), (b)]. Large rhizoliths also occur at American Museum vertebrate quarries $\mathrm{A}$ and $\mathrm{B}$, though they are not well developed there. Well preserved rhizoliths of very large trees (with bole diameters up to $2.2 \mathrm{~m}$ ) are locally common in the lower part of the Jebel Qatrani Formation, about $25 \mathrm{~km}$ west of Garet el Gehannam [Figure 1, Plate 4(c)]. These trees are clearly much larger than any in the Fayum region that are represented by fossil logs and incontrovertibly are autochthonous [Plate 4(c)]. "Forests" of smallerr hizoliths [Plate 5(a)] are common throughout the Jebel Qatrani Formation where the pebbly desert surface has been disturbed and the underlying friable sand was subjected to wind erosion. In the Madwar el Bighal and Bahariya Oasis areas (Figure 1), thick (up to $35 \mathrm{~m}$ ) fine sandstone and coarse silt sequences at the base of the Jebel Qatrani Formation are composed almost exclusively of rhizoliths [Plate 5(b)]. Some of these are mangrove in origin (Bown, in press), resembling mangrove rhizoliths recently described from the eastern Arabian Peninsula by Whybrow \& McClure (1980). Mangrove rhizoliths, taken in conjunction with conformably underlying nearshore marine and, possibly deltaic and mudflat sediments of the upper Qasr el Sagha Formation (upper Eocene) suggest a lowland nearshore setting for deposition of the lower part of the Jebel Qatrani Formation.

\section{The Paleontological Perspective}

Invertebrate and trace fossils (T. M. Bown)

Poorly preserved gastropods and bivalves recovered from three localities in the lower part of the Jebel Qatrani Formation were studied by John H. Hanley of the U.S. Geological Survey. Hanley recognizes two morphotypes of bivalves in one collection, which probably represent distinct genera. One morphotype has a taxodont hinge dentition. Because strictly freshwater bivalves of the family Unionidae do not possess taxodont hinge dentitions, it is likely that these bivalves are of a marine or brackish water taxon. The bivalves are filled with sediment, suggesting that they might have been transported a short distance and buried alive. Such catastrophic burials are common in environments with a ". . . seasonally brackish influence in the distal portion of a dominantly freshwater fluvial system ..." (J. H. Hanley, pers. comm., 1981). 
The one or more morphotypes of Jebel Qatrani Formation gastropods are of uncertain affinities owing to poor preservation, but these have oblique axial and spiral shell sculpture that is reminiscent of cerithid gastropods. Cerithids often occur in abundance in brackish or marine habitats and because the shells are filled with sparry carbonate, or in some instances what is probably dolomite, they were not filled with sediment after death and probably underwent very little transport.

A third assemblage of dominantly marine or brackish water invertebrates was recovered from near the top of Widan el Faras, near the top of the Jebel Qatrani Formation (Beadnell, 1905; Bowen \& Vondra, 1974, p. 130).

Samples of freshwater limestones and marly dolomitic limestones from five localities in the Jebel Qatrani Formation distinct from those localities containing brackish water mollusks were submitted to Richard M. Forester of the U.S. Geological Survey for examination for ostracodes and charophytes. All of the samples contained several ostracode molds, charophyte internal molds and casts, and charophyte gyrogonites. None could be identified to genus, but Forester believes that the ostracodes are probably members of the non-marine family Cyprididae.

Based on the total assemblage from these samples of carbonates, Forester offers the following tentative interpretation of their paleoenvironment.

The total assemblage... indicates that this was a freshwater environment. The salinity was very probably below $2 \mathrm{ppt}$ and quite possibly below $1 \mathrm{ppt}$. The seeming absence of any closed basin systems suggests one of two probable situations; namely the water is draining (i.e., a river or shallow spillpoint lake) and thereby remains fresh regardless of the associated climate, or the precipitation/ evaporation ratio is greater than one or at least one.

The dominance of charophytes and mollusks suggests that the water depth was shallow, probably less than ten feet $(3 \mathrm{~m})$. The absence of a diverse ostracode assemblage suggests that these samples are either on the margin of a larger system or from a system with "pond" characteristics, i.e., shallow throughout its extent. The abundance of charophytes and the seeming absence of clastics suggests that this was a low energy environment. If one combines the notion of shallow water with low energy it would suggest either a protected aquatic setting, i.e., no wind energy and/or few or no clastics getting into this system. I cannot speculate on the thermal regime, but everything thus far points to, but does not demonstrate, tropical to subtropical climates.

The ostracodes and to a lesser extent the charophytes can occur in both temporary or permanent water bodies. The large cyprids like the ones in these samples are often found in temporary water bodies that fluctuate in level over some period of time.

In summary, I would guess that these samples came from a shallow-lake-marsh like environment or perhaps a very low energy stream. The water was fresh, with a high $\mathrm{pH}$ (above 8.0) and probably supported abundant algal, subaquatic and emergent macrophyte vegetation. The environment may have been protected from wind energy (perhaps by trees) and was isolated from a clastic source. The water level probably fluctuated and the system may have even dried up occasionally. The water chemistry was dominated by $\mathrm{Ca}(\mathrm{HCO} 3)$ and possibly $\mathrm{Na}$ and $\mathrm{SO} 4$.

In addition to the molluskan fauna, the Jebel Qatrani Formation yields a large ichnofauna (trace fossils). The traces of at least 15 organisms are believed to be represented (Bown, in press), including trails and filled burrows of sediment-feeding organisms, burrows of sediment-dwelling animals, and nest structures of subterranean termites [Plate 5(c)]. Tentative identification of the agents responsible for trace fossils in the Jebel Qatrani Formation include annelid worms, crustaceans, insects, and vertebrates.

The presence of freshwater ostracodes, charophytes, the varied brackish water mollusks, and ichnofossils suggests, respectively, (1) the development of at least periodic large, shallow, low salinity floodplain ponds, (2) a nearshore fluvial setting, and (3) an optimal soil environment for a variety of wet substrate sediment feeders and drier sediment-dwelling organisms. (1) and (3) directly contradict a sahélien type of environ- 
ment with a low moisture regime, periods of extensive drought, calcrete development, and, presumably, a species-poor invertebrate biota.

Vertebrate fossils (T. M. Bown and E. L. Simons)

Terrestrial fossil vertebrates are traditionally believed to be notoriously poor indicators of paleoenvironments because of a lack of well documented analogs for extinct taxa. Paleofloristic, geological, or other data are generally used to assign vertebrates to a particular paleoenvironment. Perhaps this is why Kortlandt's few references to vertebrates from the Fayum deposits are so quixotic. Having argued that vegetation was sparse in the Jebel Qatrani paleoenvironment, Kortlandt (1980, p. 281) departs at considerable length from his environmental reconstruction to explain further this sparseness.

Based only on rhizoliths (". . . roots and rootlets in situ, which are not thicker than $4 \mathrm{~cm}$..."), Kortlandt concluded that the Jebel Qatrani paleoenvironment was dry with only local gallery forest along streams, interspersed with broad areas of scrubland (". . . small-tree type of woodland ...") and open plains ("savanna"). That is, plant cover was low. "From this inference, it would follow that an approximate model of the Fayum ecosystem is represented by the present-day Senegal River delta". (Kortlandt, 1980, p. 281.) "If the Oligocene Proboscidea and other pachyderms had the same habits as their modern relatives in East Africa (and to a lesser extent on Ceylon) they would certainly, in years of severe drought, have destroyed most of the trees in the Fayum". (Kortlandt, 1980, p. 281.)

Having mustered elaborate interpretations to explain away thousands of fossil logs in Oligocene rocks of the Fayum area, Kortlandt offers yet another line of specious speculation to explain their "absence" through destruction by early elephants. Here, he is again on unstable ground. A brief review of the Fayum late Eocene and Oligocene vertebrate fauna and what is known or suspected about their living habits is illustrative.

The first vertebrate fossils were found in the Fayum Depression area by Schweinfurth in 1879. These faunas have been added to through more than a century of collecting, including stratigraphically well documented collections obtained for Yale and Duke Universities and the Cairo Geological Museum by E. L. Simons and co-workers in Egypt from 1961 to the present. However, there have been few recent attempts at a general conspectus of these faunas. The most complete mammalian species list for the Jebel Qatrani Formation (74 species) was published by Simons (Simons \& Wood, 1968), but no such list exists for the lower vertebrate fauna, which includes sharks, rays, lungfish, turtles, crocodiles (two species, el-Kashab, 1977), a false gavial (one species, elKashab, 1977), at least one snake, and perhaps four birds (Table 3). Despite review and synonymy of some Fayum primates (Simons, 1974; Kay et al., 1981), Wood, in Simons \& Wood, 1968), carnivorous mammals (Simons \& Gingerich, 1974), and hyracoids (Meyer, 1978), the number of mammalian species is still near 70 (Table 3). Though this is not a large figure for a fauna from rocks representing a tropical to subtropical depositional setting and accumulation for a long time, it is clear that sedimentary factors are in part responsible. Most of the vertebrates occur in coarse bar deposits and floodplain deposits make up a relatively small part of the section. Moreover, the microvertebrate fauna is inadequately represented, as is shown by the first recovery of insectivores (two taxa) and a second taxon of small parapithecid primate from the lower part of the Jebel Qatrani Formation in 1981. 
THE FAYUM PRIMATE FOREST REVISITED

Table 3

Fossil vertebrates of the Jebel Qatrani Formation (Oligocene) of Egypt

Class Chondrichthyes

Subclass Elasmobranchii

Order Selachii

Order Batoidea

Carcharhinus sp. (possibly Carcharias)

other unidentified sharks (at least two)

Myliobatis sp.

Aetobatis sp.

Class Osteichthyes

Subclass Actinopterygii

Infraclass Teleostei

Subclass Sarcopterygii

Order Dipnoi

unidentified teleosts

unidentified lungfish

Class Reptilia

Subclass Anapsida

Order Chelonia

Testudo ammon Andrews 1903

Testudo beadnelli Andrews 1906

Testudo isis Andrews 1906

Testudo sp., cf. T. peripiana Deperet

Podocnemis blanckenhorni Von Reinach 1903

Podocnemis fajumensis Andrews 1903

Stereogenys libyca Andrews 1903

Pelomedusa progoleata Von Reinach 1903

Subclass Archosauria

Order Crocodilia

Crocodylus articeps Andrews 1905

Crocodylus megarhinus Andrews 1905

Tomistoma gavialoides Andrews 1905

Order Squamata

unidentified booid

Class Aves

Order Aepyornithiformes

Stromeria fajumensis Lambrecht 1929

Eremopezus sp.

Order Ciconiiformes

Goliathia andrewsi Lambrecht 1930

Palaeoephippiorhynchus dietrichi Lambrecht 1930

Class Mammalia

Order Proteutheria?

Ptolemaia lyonsi Osborn 1908

Qarunavus meveri Simons \& Gingerich 1974

Order Insectivora

undescribed new genus and species 1

undescribed new genus and species 2

Order Macroscelidea

Metoldobotes stromeri Schlosser 1910

Order Chiroptera

Suborder Microchiroptera

undescribed new genus and species

undescribed new genus and species 2

Family Phyllostomatidae?

Vampyravus orientalis Schlosser 1910 
Table 3 continued

Order Primates

Superfamily Parapirhecoidea

Parapithecus fraasi Schlosser 1910

Parapitinecus grangeri Simons 1974

Apidium phiomense Osborn 1968

Apidium moustafi Simons 1962

Apidium, sp. nov.

Superfamily Hominoidea

undescribed parapithecid, gen. et sp. nov.

Propliopithecus haeckeli Schlosser 1910

Propliopithecus markgrafi (Schlosser) 1910

Propliopithecus chirobates (Simons) 1965

Aegyptopithecus zeuxis Simons 1965

Oligopithecus savagei Simons 1962

Order Rodentia

Phiomys andrewsi Osborn 1908

Phiomys paraphiomyoides Wood 1968

Phiomys lavocati Wood 1968

Metaphiomys beadnelli Osborn 1908

Metaphiomys schaubi Wood 1968

Paraphiomys simonsi Wood 1968

Gaudeamus aegypticus Wood 1968

Phiocricetomys minutus Wood 1968

Order Creodonta

Family Hyaenodontidae

Subfamily Hyaenodontinae

Metasinopa aethiopica (Andrews) 1906

Metasinopa fraasi Osborn 1909

Apterodon altidens Schlosser 1910

Apterodon macrognathous (Andrews) 1904

Apterodon minutus Schlosser 1910

Pterodon africanus Andrews 1903

Pterodon leptognathous Osborn 1909

Pterodon phiomensis Osborn 1909

Subfamily Proviverrinae

Isohyaenodon brachycephalus (Osborn) 1909

Masrasector aegypticus Simons \& Gingerich 1974

Order Proboscidea

Masrasector sp.

Suborder Moeritherioidea

Family Moeritheriidae

Suborder Elephantoidea

Moeritherium andrewsi Schlosser 1911

Family Palaeomastodontidae

Palaeomastodon beadnelli Andrews 1901

Palaeomastodon barroisi Pontier 1907

Palaeomastodon intermedius Matsumoto 1922

Palaeomastodon parvus Andrews 1905

Phiomia serridens Andrews \& Beadnell 1902

Phiomia minor (Andrews) 1904

Phiomia osborni Matsumoto 1922

Phiomia wintoni (Andrews) 1905

Order Sirenia

Family Dugongidae

$$
\text { Eotheroides sp. }
$$

Order Embrithopoda

Family Arsinoitheriidae

Arsinoitherium zitteli Beadnell 1902

Arsinoitherium andrewsi Lankester 1903 
Table 3 continued

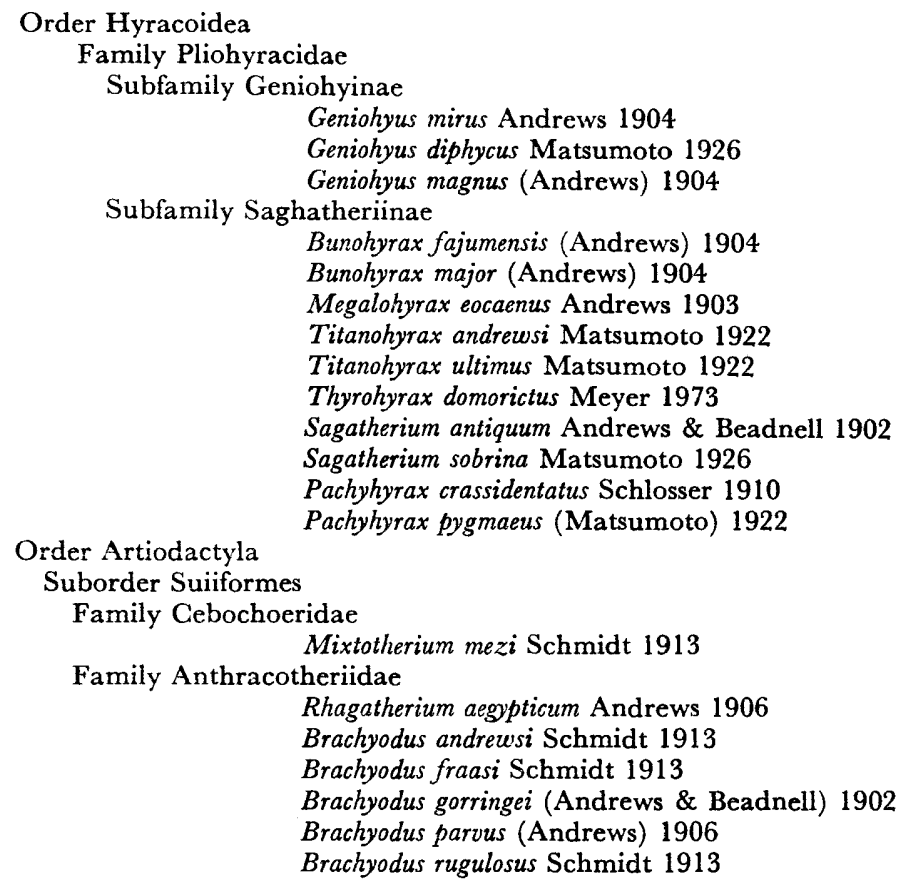

Though it is clear that living elephants do considerable damage to forests in parts of Africa and southern Asia, Moeritherium was only slightly larger than a hog, and Phiomia and Paleomastodon, the remaining Jebel Qatrani proboscideans, stood less than $1.5 \mathrm{~m}$ tall at the shoulder (Osborn, 1936). Even Arsinöitherium, largest of the Oligocene land mammals of Egypt, reached only $1.75 \mathrm{~m}$ (Osborne, 1910), much smaller than the 3.0$3.75 \mathrm{~m}$ commonly attained by living African Loxodonta. It is difficult to imagine any of these mammals doing any appreciable damage to trees greater than $30 \mathrm{~m}$ tall (as exemplified by the fossil logs), or 1-2.2 $\mathrm{m}$ in diameter (as exemplified by both logs and rhizoliths). They may well have damaged smaller plants, but there is no evidence of this.

At least four-fifths of the mammal fauna of the Jebel Qatrani Formation was dominantly or exclusively herbivorous in diet, including at least 50 species in six orders; Primates, Rodentia, Proboscidea, Embrithopoda, Hyracoidea, and Artiodactyla. This diversity attests to a large and varied flora, particularly of larger plants that could be eaten by large browsing animals. The greatest species diversity (13) is in the Hyracoidea (Meyer, 1978), and these animals are also among the most plentiful fossils. The feet of hyraxes are plantigrade and are not very suitable for fast running in open spaces. Living species are adept climbers, both on rocks and in trees. Similarly, none of the other Fayum Oligocene mammals show any particular adaptations for fast running. The anthracotheres, Arsinöitherium, and the proboscideans may well have been amphibious (for example, summaries in Romer, 1966).

Kortlandt (1980, p. 286) is puzzled by ". . . the surprising paradox that no primate fossils have been found in the Eocene rain forest facies (including Qasr el Sagha), in spite 
of the presence of other land mammals, whereas they abound in the Oligocene deposits of Jebel el Qatrani that have no indication of the presence (or nearby presence) of a rain forest". Evidence of an "Eocene rain forest" is based on Engelhardt's identification of plants from a locality in the Qasr el Sagha Formation, an upper Eocene sequence conformably underlying the Jebel Qatrani Formation.

Well preserved plant remains are rare in the Jebel Qatrani Formation because of the small amount of preserved fine grained floodplain deposits, an effect of the winnowing out of these deposits through reworking by laterally shifting meandering streams in a more-or-less stable tectonic setting (for example, Allen, 1978; Kraus, 1980). Nevertheless, they do occur there, particularly in a tabular zone of drab and/or carbonaceous shale developed at about the $210 \mathrm{~m}$ level (Bown, in press, figure 8), where about six leaf-bearing quarries were developed by S. L. Wing in 1981. Fossil plants in the upper part of the Qasr el Sagha Formation (including those at several new localities discovered by S. L. Wing in 1981) occur in fine grained nearshore marine and/or marginal fluvial rocks. The ". . other land mammals ..." Kortlandt cites from the Qasr el Sagha consist of a single lower jaw of Apterodon (Simons \& Gingerich, 1976), a single talus of Brachyodus, Barytherium teeth, and some equivocal remains, possibly of Arsinöitherium. Other mammals in Kortlandt's "rain forest facies" of the Qasr el Sagha are cf. Dorudon (a whale), Moeritherium (a presumed amphibious proboscidean), and Eotheroides (a sirenian) (Simons, in Simons \& Wood, 1968). Moreover, the Qasr el Sagha Formation is principally nearshore marine (Vondra, 1974), the upper part yielding the terrestrial mammals may be in part deltaic or estuarine, and the associated fauna includes abundant marine and brackish water invertebrates, sharks, skates, rays, sea snakes, and marine fish. Clearly, the absence of primates and larger terrestrial vertebrates there is something less than a "surprising paradox".

In summary, evidence from the Qasr el Sagha and Jebel Qatrani fossil vertebrates supports our contention that the Jebel Qatrani Formation paleoenvironment was damp, coastal, and densely vegetated. The presence of shark and ray teeth and mouth parts in stream channel sandstones of the Jebel Qatrani Formation and the recovery of a sirenian in the upper part of the formation in 1978 corroborate evidence of some of the mollusks and of mangrove rhizoliths that these sediments accumulated on a lowland, tide-influenced coastal plain. Evidence of a densely vegetated, tropical to subtropical forest in Jebel Qatrani times is also forthcoming from large collections of fossil fruits, discussed below, and the remainder of the Fayum flora.

Plant fossils (S. L. Wing and B. H. Tiffney)

Kortlandt (1980) cites a variety of paleobotanical evidence to substantiate his hypothesis that the Oligocene paleoenvironment of the Fayum area was an open savanna with scattered areas of shrubs and small trees growing under a seasonally very arid climate (sahélien). A re-examination of the paleobotanical literature used by Kortlandt reveals that the data suggest the presence of areas of monsoonal rainforest, perhaps interspersed with areas of scrubland and savanna. Even more revealing are plant fossils collected in 1980 and 1981. In the interest of clarity, we will consider sequentially Kortlandt's interpretation of the paleobotanical data derived from fossil fruits, leaves, and pollen. We conclude with observations on phytogeography and a survey of other studies of the region. New information is presented on the fossil fruits and leaves. 
(1) Fossil fruits. Kortlandt (1980, p. 281) reports the presence of " . . fruits or seedpods of marsh-dwelling and riparian arums (Araceae) ..." in the Jebel Qatrani Formation and refers to Simons (Simons \& Wood, 1968). The latter article observed that the fruits probably belonged to one of three genera in the Araceae: Scindapsus Schott, Cyrtosperma Griff., or Epipremnum Schott. These fruits were originally described as Teichosperma spadiciflorum Renn. (Pandanaceae) by Renner (1907) and by Kraüsel \& Stromer (1924) from the Fayum. Reinvestigation of this plant, based on material collected in the 1960s by Simons and on large collections made in 1980 and 1981, has demonstrated that these fossils clearly belong in Epipremnum.

The fossils are compound fruits [Plate 6(a), (d)], consisting of a weak parenchymatous central axis [Plate $7(\mathrm{c})]$ about which the individual berry-like fruits are arranged in a loose spiral. The compound structures average $10-13 \mathrm{~cm}$ in length by $4-7 \mathrm{~cm}$ in breadth, while the individual fruits average about $0.8 \mathrm{~cm}$ in diameter and $2.0 \mathrm{~cm}$ in length. The fossils are preserved as iron-rich silicate petrifactions, and the anatomical detail is excellent [Plate 6(d); Plate 7(a), (b)]. The individual fruits consist of a one to incompletely two-loculed ovary bearing four to six reniform seeds on two parietal placentae [Plate 6(b), (c)]. The anatropous seeds [Plate 7(a), (b)] possess a thick testa with an outer surface of elongate, smooth epidermal cells.

Though a detailed description of these fossils is still in progress, their characters leave little doubt to their assignment in Epipremnum. Modern species of Epipremnum are lianes (large vines) which possess large (approximately $1 \times 0.3 \mathrm{~m}$ ) thin leaves and climb tens of meters into the forest canopy. They are today restricted to the monsoonal forests of Indomalaysia and the western Pacific Islands (Engler \& Krause, 1908). The presence of Epipremnum in the Oligocene of the Fayum suggests both the existence of at least a locally well-developed forest and of a much higher rainfall than that postulated by Kortlandt. It must be emphasized that the weak construction of these infructescences would not stand up to long distance fluvial transport, and that they certainly were part of the local Oligocene flora of the Fayum.

Other fruits collected in 1981 have been identified provisionally as representing two species of Annonaspermum (Annonaceae), and one species each of Canarium (Burseraceae), Icacinicarya (Icacinaceae), and Eohypserpa (Menispermaceae). Two other forms are not yet identified. The affinity of the identified fruits and seeds to living species inhabiting Indomalaysia reinforces our interpretation of the Fayum flora as a rich tropical forest growing under at least adequate rainfall.

(2) Fossil leaves. Kortlandt (1980) states that the presence of fossil leaves in the Eocene sediments of the Fayum, and by contrast, the absence of identified leaves from the Jebel Qatrani Formation ". . . suggests a change of climatic and/or sedimentary conditions, i.e. possibly a change from a tropical humid to a more or less sahélien climate in the deposition area" (Kortlandt, 1980, p. 286). His concluding phrase, a priori, accepts a climatic solution, and he ignores the potential for depositional control of preservation that he, himself, suggests at the start of the sentence. Unfortunately, the presence or absence of leaves in the fossil record says little or nothing about regional climate; occurrence is much more dependent on the local physical and chemical conditions at the site of deposition, and on sedimentological controls such as those noted in the preceding section. The Eocene-Oligocene transition in the Fayum area records an environmental change from the mixed fluvial and nearshore marine Qasr el Sagha Formation to the 
fluvial Jebel Qatrani Formation (Vondra, 1974). The preservational environments entailed in this shift would probably swamp any discernable effects of changing climate. In 1981, collections of well preserved fossil leaves were obtained from several localities in a laterally extensive drab mudstone containing local carbonaceous shales in the middle part of the Jebel Qatrani Formation. Preliminary study of these leaves by S. L. Wing reveals at least 15 species. The flora includes the floating aquatic plants Salvinia and Nelumbo, a wetland form resembling Typha (cattail), and the fern Acrostichum, living species of which are restricted to brackish or freshwater on the landward side of mangrove forests. Tree and shrub forms include Cynometra (a genus of leguminous trees having several mangrove species), Triplochiton (Sterculiaceae), one species each in Ochnaceae and Sapotaceae, fan palms, and at least six kinds of unidentified dicot leaves. Thus far, identification of the fossil leaves independently corroborates information from the fossil fruits suggesting that the Oligocene paleoenvironment included areas of wet, tropical forest.

(3) Fossil pollen. Kortlandt's data on the palynofloras of the mid-Tertiary of North Africa are derived from Kedves (1971). Kortlandt summarizes that near the EoceneOligocene boundary, there is an increase in the pollen of ". . Restionaceae (Incertus group), engelhartoid forms, the Rurensis group, smooth pollen of palms, Araucariacites, Graminidites, and Amaranthaceae or Chenopodiaceae, i.e., in general, plants which either belong to the grasses and their ecological analogues or are otherwise predominantly characteristic of more or less open habitats" (Kortlandt, 1980, p. 287).

Several cautionary comments are offered concerning Kortlandt's vegetational interpretation of these data. First, to an extent which depends on the particular environment of deposition, palynofloras indicate changes in broad regional vegetation rather than that of any particular location. Second, wind pollinated plants, such as grasses, amaranths, and chenopods produce very large quantities of small, easily dispersed pollen. As a result, they are likely to be disproportionately represented when compared to the usually insect pollinated plants of dense forests. Third, many of the taxa which Kortlandt mentions are neither grasses nor grass analogs. Engelhardtia, Araucaria, and palms are all trees of varying sizes. The pollen genus Graminidites has ambiguous ecological significance because it may include pollen of wetland grasses and bamboos. Both Amaranthaceae and Chenopodiaceae have members that inhabit open, wet ground.

(4) Phytogeography. The geographic distributions of modern relatives of the fossil plants from the Fayum (for example, Tables 1 and 2) provide further evidence against these remains having been transported from an area to the south. Several taxa, including Dadoxylon, Epipremnum, Gynotrochoxylon, and perhaps Atherospermoxylon find their presumed modern counterparts in Indomalaysia and Australia. Several others, including Quercoxylon, Ficoxylon, and Podocarpoxylon are related to modern genera with primarily extraAfrican distributions. Ebenoxylon, Combretoxylon, Anogeissuxylon, Sapindoxylon, and Sterculivxylon all can be related to modern genera with both African and extra-African species, the latter often occurring in the New World or Indomalaysian tropics. The significance of the distribution patterns of these modern relatives of the Fayum fossils is in their historical origin. These patterns are the end product of the geographic restriction of a host of taxa which, in the Paleogene, were widely distributed along the shores of the Tethys seaway from Indomalaysia to northwest Europe, and perhaps as far as North America (Reid \& Chandler, 1933; Chandler, 1954; 'Tiffney, 1980). Because Africa 
formed the southern shore of the central part of Tethys, the Oligocene floras of northern Egypt would be expected to support taxa of Indomalaysian affinities, which are indeed present (for example, Dadoxylon, Epipremnum, Gynotrochoxylon; Schnell, 1976). The existence of these elements in the Oligocene flora of the Fayum suggests a maritime forest of dominantly Tethyian heritage, rather than an allochthonous flora derived from the interior of Africa.

(5) Other studies. Before turning to a summary of the paleobotanical data, it is appropriate to briefly review the vegetational reconstructions offered by other authors for the Oligocene of eastern North Africa. Louvet (1971), on the basis of fossil woods from Libya, Algeria, and Egypt, shows a narrow band of "forêt dense" along the southern shore of the Tethys in the middle Oligocene. To the south of this, he indicates the presence of "savanna". In eastern North Africa, the juncture between these two zones is marked as tentative, and appears to run directly through the Fayum. Axelrod (1975) and Axelrod \& Raven (1978) provided vegetational reconstructions for the Oligo-Miocene, and depict a band of subtropical laurel forest in a position similar to that suggested by Louvet for his dense forest. Again, the Fayum appears to be close to the southern edge of this forest unit, and again the authors suggest the presence of savanna to the south. Axelrod and Raven's reconstruction is accepted by Bakker (1978), and extended into the Miocene. Bakker also comments on circum-Tethyian tropical climates in the early to middle Tertiary.

In the light of the reconstructions by Louvet, Axelrod, Axelrod \& Raven, and Bakker, it is important to locate the Jebel Qatrani Formation lithotope in relation to the Oligocene marine strandline. Beadnell (1905) and Bowen \& Vondra (1974), and this study (above) note rare occurrences of marine or brackish water mollusks and shark teeth in the Jebel Qatrani Formation. Furthermore, one of the fossil woods (Gynotrochoxylon) is allied with the modern genus Gynotroches Blume, a member of the Rhizophoraceae. Most extant members of this family are coastal mangroves. This corroborates morphologic evidence (pneumatophores) that some of the large rhizolith masses in the lower part of the Jebel Qatrani Formation (mentioned in the geological section above) are mangrove in origin (see also Bown, in press). Both facts strongly suggest that the Jebel Qatrani Formation was deposited near the sea and was therefore included in the belt of coastal forest suggested by the above authors in their floral reconstructions.

(6) Summary. In conclusion, we strongly suggest that the paleobotanical data are not, as Kortlandt implies, unanimously supportive of a dry sahélien vegetation for the Oligocene of the Fayum. Rather, these data suggest the presence of tall coastal and perhaps riverine forests, growing under adequate, and perhaps seasonal, rainfall. These forests may have extended for a considerable distance inland from the Fayum area, or they may have been interspersed with and given way to areas of savanna and shrubland; there are no known Oligocene rocks in Egypt south of the Fayum and Bahariya Oasis areas, and the data at hand are not sufficient to discriminate these possibilities.

The Fayum fossil primates (J. G. Fleagle)

Along with his reinterpretation of the paleoenvironment of the Jebel Qatrani Formation, Kortlandt (1980) questioned interpretations put forth regarding arboreal habits of the Fayum primates Apidium phiomense and Aegyptopithecus zeuxis. He argues that these early 
anthropoids were likely to have been more terrestrial than earlier authors believed, for several reasons.

First, he argues that since there were very few trees available in the Fayum "delta", the primates must have moved on the ground. As discussed above, the Fayum area supported plenty of trees to accommodate a wide range of totally arboreal primates.

Second, he argues that the large canines of Aegyptopithecus and Propliopithecus (including "Aeolopithecus", Kay et al., 1981) are likely to be indicative of a terrestrial habitus. Large canines, per se, are not particularly indicative of terrestrial habits. Many extant arboreal anthropoids such as gibbons [Figure 2(a),] leaf-monkeys [Figure 2(b)], or orangutans have canines that are relatively as long or longer (in the males) than those of the more terrestrial African apes or of Aegyptopithecus zeuxis [Figure 2(c)]. It is certainly true that sexual dimorphism in body size and canine size is positively correlated with terrestriality and both Aegyptopithecus and Apidium show evidence for body size dimorphism (Fleagle et al., 1980). Nevertheless, the same amount of body size dimorphism as is estimated for these Oligocene species is found in many living arboreal taxa, including Alouatta sp.

Third, Kortlandt argues that arboreal interpretations of primate behavior are heavily influenced by ". . . long-standing indoctrination (that is) difficult to overcome when one is not familiar with the everyday life of primates in the wild". Such biases do not seem appropriate here since the authors primarily responsible for interpreting the locomotor habits of the Fayum primates have been far more eager than most to suggest terrestrial or quadrupedal habits for fossil hominoids (Conroy \& Fleagle, 1972; Zwell \& Conroy, 1973; Jenkins \& Fleagle, 1975; Simons, 1972). Likewise, when a "fossil-digger" primarily concerned with these interpretations has observed (and filmed) the naturalistic behavior of 31 species (17 genera) of nonhuman primates on three continents, he can hardly be considered "not familiar with the everyday life of primates in the wild".

Finally, Kortlandt suggests that those analysing the limb bones of Aegyptopithecus and Apidium have not given due consideration to the possibility that these primates were ". . . to an important extent, ground-walkers, runners, and leapers". As Kortlandt rightly points out, arboreal and terrestrial habits are not wholly dichotomous. Many primates which are dominantly terrestrial in travel and foraging such as patas monkeys, baboons, or vervets regularly sleep and feed in trees. Likewise, such predominantly

Figure 2. Lateral view of the cranium and lower jaw of the whitehanded gibbon, Hylobates lar (a), and the banded leaf-monkey, Presbytis melalophos (b), two arboreal higher primates from Malaysia compared with Aegyptopithecus zeluxis (c) to show that the canines in the Oligocene fossil are no larger than those found in living arboreal species.

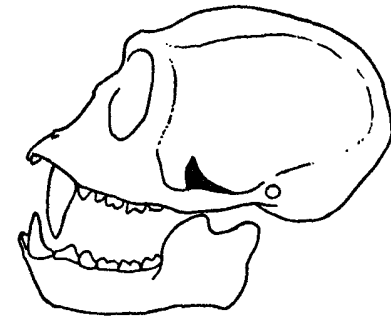

(a)

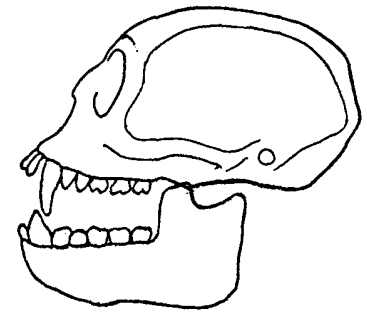

(b)

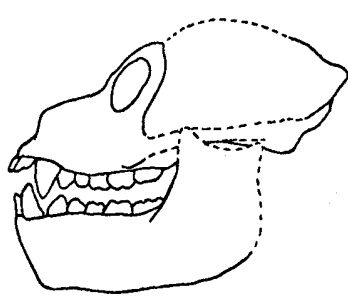

(c) 
arboreal species as howling monkeys, capuchins, squirrel monkeys, or banded leafmonkeys occasionally come to the ground to feed.

Nevertheless, quadrupedal higher primates such as baboons, patas monkeys, vervets, or pig-tailed macaques which normally travel from food source to food source along the ground, invariably show a distinctive suite of features in their forelimb anatomy that distinguishes them from more arboreal quadrupedal species (Jolly, 1967; Fleagle \& Schneider, unpublished data). In the humerus of arboreal quadrupeds, the medial epicondyle is usually large and directed medially [Figure 3(A)], rather than posteriorly [Figure 3(в)], as in terrestrial quadrupeds (and most cercopithecoids). In most arboreal quadrupeds and the Fayum anthropoids, the capitular side of the distal articular surface is relatively shallow [Figure 3(c)] and there is no pronounced lateral edge on the olecranon fossa [Figure $3(\mathrm{E})]$, whereas in terrestrial quadrupeds, the capitular side of the humerus is relatively deep [Figure 3(D)] and forms a pronounced flange on the lateral side of the olecranon fossa [Figure 3(F)]. In terrestrial quadrupeds, the medial trochlear margin shows a more pronounced distal flaring [Figure 3(н)] than that found in arboreal species [Figure 3(G)], and there is never a well developed brachialis flange [Figure 3(J)].

On the humeral head of terrestrial quadrupeds, the greater tuberosity is much larger than the lesser, it is aligned anteroposteriorly and extends well anterior to the articular

Figure 3. Anterior and distal views of the lower part of the left humerus in two extant arboreal quadrupeds, (i) the black and white colobus monkey (Colobus guereza) and (ii) the red howling monkey (Alouatta seniculus) ; (iii) Aegyptopithecus zeuxis, an Oligocene anthropoid; and (iv) an extant terrestrial quadruped, the patas monkey (Erythrocebus patas).

(i)

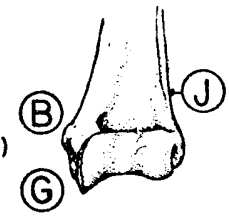

(ii)

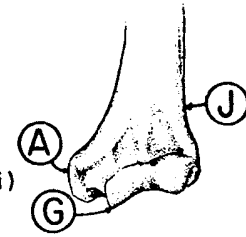

(iii)

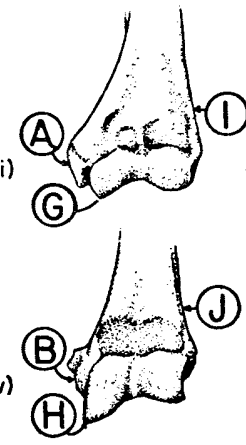

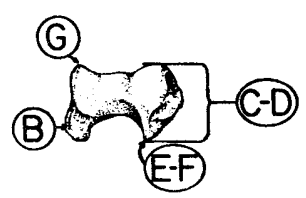

(G)

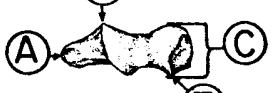

(E)<smiles>[18OH]</smiles>
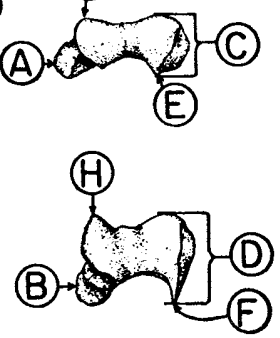
surface, presumably to make $M$. supraspinatus a more effective protractor. In arboreal quadrupeds, the greater and lesser tuberosities are more equal in size and are generally located laterally and medial relative to the articular surface, contributing to greater gleno-humeral stability and rotational abilities. In all of these features, the humerus of Aegyptopithecus (Figure 3; Fleagle \& Simons, 1978, 1982), and to the extent that is is known, that of Apidium (Conroy, 1976) look like the humerus of an arboreal quadruped and not like that of a ground walker or runner.

Likewise, there are numerous distinctive features in the ulnae of quadrupedal primates which clearly distinguish arboreal and terrestrial species. In arboreal quadrupeds, the olecranon is long and is extended proximally in line with the shaft [Figure 4(A)]; in terrestrial species, the extension of the olecranon is posteriorly, giving the triceps insertion a greater movement when the elbow is fully extended [Figure 4(в)]. In arboreal quadrupeds, the sigmoid cavity is relatively shallow [Figure $4(\mathrm{c})]$; in terrestrial quadrupeds, it is deep [Figure 4(D)], and buttressed distally by a high coronoid process [Figure $4(E)$ ]. In terrestrial species, the radial facet in the ulna is more deeply excavated [Figure 4(F)] than the small facet on the ulna of arboreal species [Figure 4(G)], reflecting the greater size of the radial head. In arboreal quadrupeds, the ulnar shaft tends to be deep anteroposteriorly and convex on the posterior surface [Figure $4(\mathrm{H})$ ], a configuration which gives greater structural strength when the monkey walks with a flexed elbow (Preuschoft, 1975). In terrestrial species, the ulnar shaft is more nearly round and often shows a concave posterior surface in the distal moiety [Figure $4(\mathrm{~J})$ ]. In all of these features, the ulna of Aegyptopithecus (Figure 4; Fleagle et al., 1975) looks like that of an arboreal quadruped such as Alouatta seniculus. Likewise, the few described ulnar remains of Apidium

Figure 4. Anterior and distal views of the lower part of the left ulna in two extant arboreal quadrupeds, (i) the black and white colobus monkey (Colobus guereza) and (ii) the red howling monkey (Alouatta seniculus); (iii) Aegrptopithecus zeuxis, an Oligocene anthropoid; and (iv) an extant terrestrial quadruped, the patas monkey (Erythrocebus patas).

(i)

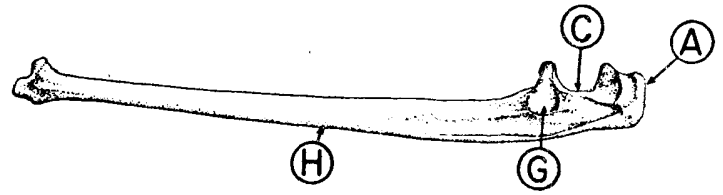

(ii)

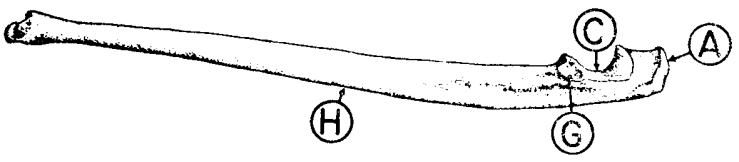

(iii)

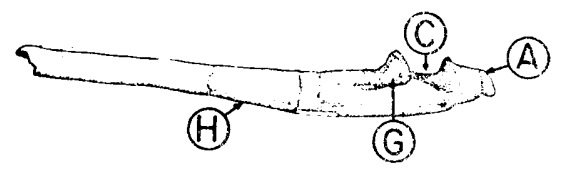

(iv)

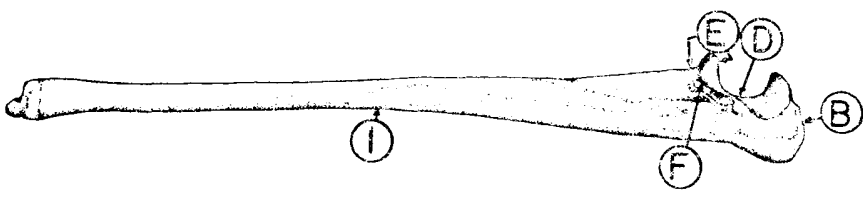


phiomense appear to be like those of an arboreal quadruped (Conroy, 1976). Neither shows any of the extreme terrestrial adaptations seen in baboons, patas monkeys, or vervets, the species cited most frequently by Kortlandt as ecological models.

No hindlimb elements of Aegyptopithecus have been described, except a hallucal metatarsal which indicates a strongly grasping foot. The more abundant hindlimb elements of Apidium phiomense all indicate an arboreal, quadrupedal leaping adaptation (Fleagle, 1980; Fleagle \& Simons, 1979; Conroy, 1976).

Kortlandt (1980) has suggested that the repeatedly observed morphological similarities between Aegyptopithecus zeuxis and Alouatta might just reflect phyletically primitive features retained by Alouatta rather than habitus-related adaptations. The fact that these same morphological features or comparable ones readily distinguish closely related extant taxa with different locomotor adaptations (for example, Presbytis melalophos and Presbytis obscura, Fleagle, 1977, 1978; Macaca fascicularis and Macaca nemistrina, Rodman, 1979; Cercopithecus aethiops and Cercopithecus mona, personal observation) or even the more terrestrial subspecies of a geographically variable species like Presbytis entellus, surely indicates that the morphological similarities between Aegyptopithecus and the more arboreal species of Alouatta are a true reflection of their arboreal habits. Indeed, even Alouatta caraya, a species which frequently travels on the ground between forest patches, shows more terrestrial features in its forelimb than does Aegiptopithecus zeuxis.

In addition to this direct morphological evidence from the limbs that Aegyptopithecus zeuxis and Apidium phiomense were not predominantly ground-walkers or runners or leapers, there are more indirect indicators. Among living higher primates, predominantly terrestrial species tend to be larger than predominantly arboreal species. Of the Fayum anthropoids, Aegyptopithecus zeuxis barely overlaps in estimated body size with terrestrial monkeys; all of the Fayum anthropoids lie well within the size range of arboreal higher primates (Kay \& Simons, 1980).

In summary, the argument that Aegyptopithecus zeuxis and Apidium phiomense, the best known of the Fayum anthropoids, were predominantly arboreal in their locomotor habits is not the result of either an arboreal bias, an ignorance of the everyday life of primates in the wild, or failure to compare their morphology with that of terrestrial species. Rather, it is a well researched interpretation based on all the available fossil material and careful, detailed comparisons with the anatomy of extant species. As Kortlandt correctly points out, the Fayum does not tell us anything about Oligocene primates in the remainder of Africa. Likewise, Aegyptopithecus zeuxis and Apidium phiomense are not the only primate species known from the Fayum, only the ones for which we have the most complete fossil material. Propliopithecus ("Aeolopithecus") chirobates is known from a few fragmentary limb elements (a partial humerus, Fleagle \& Simons, 1978; a partial ulna, and possibly a tibia). This species appears to be another arboreal quadruped similar to Aegyptopithecus zeuxis, but smaller and perhaps somewhat more agile. There are no easily interpretable limb bones than can be confidently attributed to Parapithecus grangeri; however, there is some indirect evidence from the high-crowned molars that this species might be the most terrestrial of the Fayum primates (Kay \& Simons, 1980). With the recovery of more primate fossils from the Fayum and elsewhere in Africa, we may well find evidence of more terrestrially adapted taxa than either Aegyptopithecus or Apidium.

For the present, however, it is these species which provide our most complete picture of the behavior and ecology of Oligocene anthropoids, and it is the Fayum Province of 
Egypt that provides our only glimpse of higher primate evolution about 30 million years ago. In the absence of any evidence, it is fruitless to speculate that ". . the diversity of the Oligocene primates may have ranged from squirrel-like to gibbon-like creatures, or from animals resembling mouse lemurs (Microcebus) to such chimaeras as the extinct giant lemur Megaladapis" (Kortlandt, 1980, p. 289). As Kortlandt himself points out: "It is sad that too many university teachers prefer theories above facts as a source of truth".

\section{Conclusions}

In latest Eocene times, the nearshore marine and possibly deltaic and estuarine conditions of the Qasr el Sagha Formation gave way to nearshore Oligocene terrestrial environments as the northward movement of Africa raised the unstable shelf, causing the southern strandline of Tethys to retreat to the north. The earliest Egyptian Oligocene terrestrial environments, recorded at the base of the Jebel Qatrani Formation in the western part of the Fayum area and in the Bahariya Oasis, consisted of extensive coastal mangrove swamps that gave way to an at least partly forested interior. This coastal lowland was broken by aggrading meandering streams which emptied westward and northward, a short distance away, into the Tethyian seaway. These streams may have formed small or larger, coalesced deltaic sequences offshore, but if so they lie buried beneath middle and later Tertiary rocks north of the Fayum area, or were removed by erosion. Jebel Qatrani streams were relatively large and competent enough to transport gravels at least at periodic intervals (perhaps seasonally). The Jebel Qatrani lithotope was low and had little relief; storms and/or tidal incursions increased the salinity of the streams for several kilometers inland. These sometimes fresh and sometimes brackish river waters were inhabited by a variety of freshwater fish and other animals, among which rare, infrequent elements are brackish water mollusks, sharks, rays, and sirenians. The floodbasins of the Jebel Qatrani streams were heavily vegetated in most areas; there were areally large though shallow ephemeral non-saline ponds, soils were generally damp, and the climate was typified by adequate, though probably seasonal rainfall. Large forests of tall trees existed in much of the Fayum area and some of these as well as other floral elements resemble the tropical to subtropical flora apparently common to much of the Tethyian region from western Europe to Indomalaysia, where some of their modern relatives live today. The Jebel Qatrani forest supported a large and varied vertebrate fauna, dominated by browsing herbivores, and was the home of arboreal quadrupedal higher primates. Sediments of the upper part of the Jebel Qatrani Formation suggest this environment was somewhat more removed from the immediate shores of Tethys, but the presence of brackish water invertebrates near the top of the formation and sharks in the overlying Miocene Kashab Formation indicate that the coast was still close at hand.

Kortlandt's (1980) scenario of a sahélien environment of deposition for the Jebel Qatrani Formation is a fiction contradicted by nearly every avenue of available geologic and paleontologic evidence. His corollary hypothesis that primates in general were not adapted early for arboreal life is neither proven nor disproven by paleoenvironmental interpretations of the Oligocene of the Fayum. These interpretations are not more than a tiny facet of the evidence pertaining to a quite different problem; namely, that of primate origins and early specializations. Nevertheless, anatomical evidence presented herein 
and elsewhere previously demonstrates that the Fayum higher primates Aegyptopithecus and Apidium were both arboreal.

At first reading, Kortlandt's contribution appears to be remarkable for its interdisciplinary breadth and apparent thorough documentation. Herein lies the danger to those unfamiliar with the primary evidence. In sum, his paper is no more than an elaborated speculation, based on a literature review that is not tempered by careful firsthand field observations and familiarity with the evidence. In a synoptic study of the sort he made, it is always essential to weigh all the evidence and not just those pieces as may fit an a priori idea. Kortlandt commonly downplays some evidence in favor of older, less detailed sources. Much of his text is an intricate blend of evidence gleaned from the literature, brewed together with his own speculation and interpretation. Hypotheses are presented as fact, then are used to support additional speculation.

Kortlandt (1980, p. 292) observes that paleoecology ". . . is a rather speculative branch of science, and will always continue to be so. This is no reason, however, to neglect or ignore a substantial part of the hard evidence which is available". For Kortlandt, paleoecology is, indeed, speculation. For the rest of us it is, we hope, capable of descriptive interpretation based on evidence, and part of the hard evidence requisite to formulation of novel interpretations is first hand data. Without it, we are bound by the observations of others and confined by mistakes of the past. "The Fayum Primate Forest: Did it Exist?" The answer is yes; and, in the final analysis, Kortlandt was unable to see it for the thousands of silicified logs that got in the way.

We are grateful to Dr Bahay Issawi, Manager of the Geological Survey of Egypt (Abassayia) for his generous assistance and cooperation that has enabled us to persue our joint studies in the Fayum area and Western Desert of Egypt. We are also grateful to Mr Ahmed el Awady Kandil and Mr Abd el Ghany Ibrahim Shellaby, also of the Geological Survey of Egypt, and Dr Ragi Eissa and Baher el-Kashab of the Cairo Geological Museum for their able assistance and co-operation.

We thank P. D. Gingerich and R. F. Kay for technical review of the manuscript, and R. F. Kay, P. Birkeland, and B. el-Kashab for discussion. J. H. Hanley and R. M. Forester of the U.S. Geological Survey (Denver) studied the fossil invertebrates and provided interpretations of their paleoecological significance.

Research for this project and for field work in Egypt was supported by National Science Foundation grants BNS-80-16206 and BNS-81-14925, and Smithsonian Foreign Currency grants 70869600 and 809479 to Elwyn L. Simons, and by research grants BNS 7724921 and BNS 7924149 to John G. Fleagle. Research on fossil fruits was supported in part by National Science Foundation grant DEB-79-05082 to Bruce H. Tiffney.

\section{References}

Allen, J. R. L. (1978). Studies in fluviatile sedimentation: an exploratory quantitative model for the architecture of avulsion-controlled alluvial suites. Sedimentary Geology 21, 129-147.

Axelrod, D. I. (1975). Evolution and biogeography of Madrean-Tethyan sclerophyll vegetation. Annals of the Missouri Botanical Garden 62, 280-334.

Axelrod, D. I. \& Raven, P. H. (1978). Late Cretaceous and Tertiary vegetation history of Africa. In (M. J. A. Werger \& A. C. Van Bruggen, Eds) Biogeography and Ecology of southern Africa, pp. 77-130. The Hague: Dr W. Junk b.b.

Bakker, E. M. van Zinderen (1978). Late-Mesozoic and Tertiary palaeoenvironments of the Sahara Region. In (E. M. van Zinderen Bakker, Ed.) Antarctic Glacial History and World Palaeoenvironments, pp. 129-135. Rotterdam: Balkema. 
Ball, J. (1939). Contributions to the Geography of Egypt. Cairo: Government Press (Bulaq).

Beadnell, H. J. L. (1905). The Topography and Geology of the Fayum Prorince of Egypt. Cairo: Survey Department of Egypt.

Blanckenhorn, M. (1900). Nues zur Geologie und Paläontologie Ägyptens. Zeitschrift der Deutschen Geologischen Gesellschaft 52, 403-479.

Blanckenhorn, M. (1901). Geologie Ägyptens. Zeitschrift der Deutschen Geologischen Gesellschaft 52.

Bowen, B. E. (1970). The Stratigraphy of the Jebel el Qatrani Formation in the Fayum Depression, Egypt, U.A.R. Ph.D. Dissertation, Iowa State University.

Bowen, B. E. (1971). Paleoenvironmental interpretations of the Oligocene Jebel el Qatrani Formation, Fayum Depression, Egypt, U.A.R. Geological Society of America Abstracts with Programs, 254.

Bowen, B. E. \& Vondra, C. F. (1974). Paleoenvironmental interpretations of the Oligocene Gabal el Qatrani Formation, Fayum Depression, Egypt. Annals of the Geological Survey of Eg,pt 4, 115-138.

Bown, T. M. (1979). Geology and mammalian paleontology of the Sand Creek facies, lower Willwood Formation (lower Eocene), Washakie County, Wyoming. Geological Survey of Wyoming Memoir 2, $151 \mathrm{pp}$.

Bown, T. M. \& Kraus, M. J. (1981). Lower Eocene alluvial paleosols (Willwood Formation, northwest Wyoming, U.S.A.), and their significance for paleoecology, paleoclimatology, and basin analysis. Palaeogeography, Palaeoclimatology, Palaeoecology 34, 1-30.

Bown, T. M. (in press). Ichnofossils and Rhizoliths of the nearshore fluvial Jebel Qatrani Formation (Oligocene), Fayum Province, Egypt. Palaeogeography, Palaeoclimatology, Palaeoecology.

Boyer, B. W. (1981). Tertiary lacustrine sediments from Sentinal Butte, North Dakota, and the sedimentary record of ectogenic meromixis. Journal of Sedimentary Petrology 51, 429-440.

Buol, S. W. (1965). Present soil-forming factors and processes in arid and semiarid regions. Soil Science 99, 45-49.

Buol, S. W. \& Yesilsoy, M. S. (1964). A genesis study of a Mohave sandy loam profile. Soil Science Society of America Proceedings 28, 254-256.

Butzer, K. W. \& Hansen, C. L. (1968). Desert and River in Nubia. Madison: University of Wisconsin Press.

Ghandler, M. (1954). Some Upper Cretaceous and Eocene fruits from Egypt. Bulletin of the British Museum of Natural History, Geology 2, 147-187.

Conroy, G. C. (1976). Primate postcranial remains from the Oligocene of Egypt. Contributions to Primatology 8, 1-134.

Conroy, G. C. \& Fleagle, J. G. (1972). Locomotor behavior in living and fossil pongids. Nature 237, 103-104.

Dallimore, W. \& Jackson, A. B. (1966). A Handbook of Coniferae and Cinkgoaceae. London, Arnold.

Daniels, R. B., Nettleton, W. D., McCracken, R. J. \& Gamble, E. E. (1966). Morphology of soils with fragipans in parts of Wilson County, North Carolina. Soil Science Society of America Proceedings 30, 376-380.

Dean, W. E. \& Gorham, E. (1976). Major chemical and mineral components of profundal surface sediments in Minnesota lakes. Limnology and Oceanography 21, 259-284.

el-Kashab, B. (1977). A review of the reptile faunas of Egypt. The Geological Survev of Egyt and Mining Authority Paper 62, 1-10.

Engler, A. \& Krause, N. (1908). Araceae-Monsteroidea. In (A. Engler, Ed.) Das Pflanzenreich IV. 23B, pp. 4-139. Leipzig: Verlag Wilhelm Engelmann.

Fleagle, J. G. (1977). Locomotor behavior and skeletal anatomy of sympatric Malaysian leaf-monkeys (Presbytis obscura and Presbytis melalophos). Yearbook of Physical Anthropology 20, 440-453.

Fleagle, J. G. (1978). Locomotion, posture and habitat utilization of two sympatric Malaysian leafmonkeys (Presbytis obscura and Presbytis melalophos). In (G. G. Mongomery, Ed.) Ecology of Arboreal Folivores, pp. 243-251. Smithsonian Press.

Fleagle, J. G. (1980). Locomotor behavior of the earliest anthropoids: a review of the current evidence. Zeitschrift für Morphologie und Anthropologie 71, 149-156.

Fleagle, J. G. (1982). Locomotor adaptations of Oligocene and Miocene hominoids and their phyletic implications. In (R. L. Gochon and R. Corrucini, Eds) New Views of Ape and Human Evolution. New York: Plenum Press.

Fleagle, J. G., Kay, R. F. \& Simons, E. L. (1980). Sexual dimorphism in early anthropoids. Nature 287, 328-330.

Fleagle, J. G. \& Simons, E. L. (1978). Humeral morphology of the earliest apes. Nature 276, 705-707.

Fleagle, J. G. \& Simons, E. L. (1979). Anatomy of the bony pelvis of parapithecid primates. Folia Primatologica 31, 176-186.

Fleagle, J. G. \& Simons, E. L. (1982). The humerus of Aeg.ptopithecus zeuxis, a primitive anthropoid.

Fleagle, J. G., Simons, E. L. \& Conroy, G. C. (1975). Ape limb bone from the Oligocene of Egypt. Science 189, 135-137. 
Frevtet, P. (1971). Paléosols résiduels et paléosols alluviaux hydromorphes associés aux dépôts fluviatiles dans le Crétacé supérieur et l'Éocène basal du Languedoc. Revue de Géographie Physique et de Géologie Dynamique 13, 245-268.

Gile, L. H., Hawley, J. W. \& Grossman, R. B. (1981). Soils and geomorphology in the Basin and Range area of southern New Mexico-Guidebook to the Desert Project. New Mexico Bureau of Mines and Mineral Resources Memoir 39, 222pp.

Gile, L. H., Peterson, F. F. \& Grossman, R. B. (1965). The K horizon: a master soil horizon of carbonate accumulation. Soil Science 99, 74-82.

Gile, L. H., Peterson, F. F. \& Grossman, R. B. (1966). Morphological and genetic sequences of carbonate accumulation in desert soils. Soil Science 101, 347-360.

Goudie, A. (1973). Duricrusts in Tropical and Subtropical Landscapes. Oxford: Clarendon Press.

Goulding, M. (1980). The Fishes and the Forest, Explorations in Amazonian Natural History. Berkeley: University of California Press.

Grossman, R. B. \& Carlisle, F. J. (1969). Fragipan soils of the eastern United States. Advances in Agronomy 21, 237-279.

Hawley, J. W., Bachman, G. O. \& Manley, K. (1976). Quaternary stratigraphy in the Basin and Range and Great Plains Provinces, New Mexico and western Texas. In (W. C. Mahoney, Ed.) Quaternary Stratigraphy of North America, pp. 235-274. Stroudsburg: Dowden, Hutchinson, and Ross.

Hay, R. L. \& Reeder, R. J. (1978). Calcretes of Olduvai Gorge and the Ndolanya Beds of northern Tanzania. Sedimentology 25, 649-673.

James, N. P. (1979). Facies Models 10. Shallowing upward sequences in carbonates. In (R. G. Walker, Ed.) Facies Models, pp. 109-119. Geoscience Canada Reprint Series, no. 1.

Jenkins, F. A., Jr. \& Fleagle, J. G. (1975). Knuckle-walking and the functional anatomy of the wrist in living apes. In (R. H. Tuttle, Ed.) Primate Functional Morphology and Evolution, pp. 213-227. The Hague: Mouton.

Jolly, C. J. (1967). The evolution of baboons. In (H. Vagtborg, Ed.) The Baboon in Medical Research, pp. 427-457. Austin: University of Texas Press.

Kay, R. F., Fleagle, J. G. \& Simons, E. L. (1981). A revision of the Oligocene apes of the Fayum Province, Egypt. American Journal of Physical Anthropology 55, 293-322.

Kay, R. F. \& Simons, E. L. (1980). The ecology of Oligocene African Anthropoidea. International Journal of Primatology 1, 21-38.

Kedves, M. (1971). Presence de types sporomorphes importants dans les sediments prequaternaires egyptiens. Acta Botanica Academiae Scientarum Hungaricae 17, 371-378.

Kinsman, D. J. (1969). Modes of formation, sedimentary associations, and diagnostic features of shallowwater and supratidal evaporites. American Association of Petroleum Geologists Bulletin 53, 830-840.

Klappa, C. F. (1980). Rhizoliths in terrestrial carbonates: classification, recognition, genesis, and significance. Sedimentology 27, 613-629.

Kortlandt, A. (1980). The Fayum Primate Forest: did it exist? Journal of Human Evolution 9, 277-297.

Kraus, M. J. (1980). Genesis of a fluvial sheet sandstone, Willwood Formation, northwest Wyoming. In (P. D. Gingerich, Ed.) Early Cenozoic Paleontology and Stratigraphy of the Bighorn Basin, Wyoming, 1880-1980; University of Michigan Papers on Paleontology 24, 87-94.

Kräusel, R. (1939). Ergebnisse der Forschungreisen Prof. E. Stromers in den Wüsten Ägyptens, IV. Die fossilen Floren Ägyptens. Abhandlungen der Bayerischen Akademie der Wissenschaften, MathematischNaturwissenschaftiche Abteilung, Neue Folge 47, 1-140.

Kräusel, R. \& Stromer, E. (1924). Ergebnisse fer Forschungreisen Prof. E. Stromers in den Wüsten Ägyptens, IV. Die fossilen floren Ägyptens. Abhandlungen der Bayerischen Akademie der Wissenschaften, Mathematisch-Naturwissenschaftliche Abteilung 30, 1-48.

Longman, K. A. \& Jeník, J. (1974). Tropical Forest and its Environment. London: Longman.

Louvet, P. (1971). Sur l'évolution des flores tertiares de l'Afrique nord-équatoriale. Thèse, Université de Paris VI.

McKeague, J. A. (1965). A laboratory study of gleying. Canadian Journal of Soil Science 45, 199-206.

Meyer, G. E. (1978). Hyracoidea. In (V. J. Maglio \& H. B. S. Cooke, Eds) Evolution of African Mammals, pp. 284-314. Cambridge: Harvard University Press.

Moore, T. R. (1974). Gley morphology and soil water regimes in some soils in south-central England. Geoderma 11, 297-304.

Murphy, D. H. \& Wilkinson, B. H. (1980). Carbonate deposition and facies distribution in a central Michigan marl lake. Sedimentology 27, 123-135.

Osborn, H. F. (1910). The Age of Mammals. New York: Macmillan.

Osborn, H. F. (1936). Proboscidea, vol. I. New York: American Museum of Natural History.

Picard, M. D. \& High, L. R. (1974). Griteria for recognizing lacustrine rocks. In (J. K. Rigby \& W. K. Hamblin, Eds) Recognition of Ancient Sedimentary Environments, pp. 108-145. Society of Economic Paleontologists and Mineralogists Special Publication, no. 16. 
Preuschoft, H. (1975). Body posture and mode of locomotion in fossil primates-method and example; Aegyptopithecus zeuxis. In Proceedings of the Fifth Symposium of the Congress of the International Primatological Society, pp. 346-359.

Reid, E. \& Chandler, M. (1933). The Flora of the London Clay. London: British Museum (Natural History).

Renner, O. (1907). Teichosperma, eine monokotylen frucht aus dem Tertiär Ägyptens. Beitr. Paläontologeschicte und Geologeschicte Österreich-Ungarns und des Orients 20, 217-220.

Richards, P. W. (1966). The Tropical Rain Forest: An Ecological Study. Cambridge: Cambridge University Press.

Rodman, P. (1979). Skeletal differentiation of Macaca fascicularis and Macaca nemestrina in relation to arboreal and terrestrial quadrupedalism. American Journal of Physical Antropology 51, 51-62.

Romer, A. S. (1966). Vertebrate Paleontology, 3rd edn. Chicago: University of Chicago Press.

Ruellan, A. (1967). Individualisation et accumulation du calcaire dans les sols et les dépôts quaternaires du Maroc. Cahiers O.R.S.T.O.M. Série Pédologique 5, 421-462.

Said, R. (1962). The Geolggy of Egypt. Amsterdam: Elsevier.

Said, R. (1981). The Geological Evolution of the River Nile. New York: Springer-Verlag.

Schnell, R. (1976). Introduction a la Phytogeographie des Pays Tropicaux. tome 3. La Flore et la Vegetation de l'Afrique Tropicale. Paris: Gauthier-Villars.

Schweinfurth, G. (1882). Zur Beleuchtung der Frage über den versteinerten Wald. Zeitschrift der Deutschen geologischen Gesellschaft 34, 139-145.

Sellwood, B. W. (1978). Shallow-water carbonate environments. In (H. G. Reading, Ed.) Sedimentary Environments and Facies, pp. 259-313.

Simons, E. L. (1972). Primate Evolution: an introduction to man's place in Nature. New York: Macmillan.

Simons, E. L. (1974). Parapithecus grangeri (Parapithecidae, Old World higher primates): new species from the Oligocene of Egypt and the initial differentiation of the Cercopithecoidea. Postilla 166, 1-12.

Simons, E. L. \& Gingerich, P. D. (1974). New carnivorous mammals from the Oligocene of Egypt. Annals of the Geological Survey of Egypt 4, 157-166.

Simons, E. L. \& Gingerich, P. D. (1976). A new species of Apterodon (Mammalia, Creodonta) from the upper Eocene Qasr el Sagha Formation of Egypt. Postilla 168, 1-9.

Simons, E. L. \& Wood, A. E. (1968). Early Cenozoic Mammalian Faunas, Fayum Province, Egypt. Peabody Museum of Natural History (Yale) Bulletin 28.

Soil Survey Staff (1975). Soil Taxonomy. United States Department of Agriculture Handbook 436.

Surdam, R. C. \& Wolfbauer, C. A. (1975). Green River Formation, Wyoming: a playa-lake complex. Geological Society of America Bulletin 86, 335-345.

Tiffney, B. H. (1980). The Tertiary flora of eastern North America and the North Atlantic land bridge (abstract). Second International Congress of Systematic and Evolutionary Biology, Abstracts, p. 373.

Tomlinson, P. B. \& Craighead, F. C. (1972). Growth-ring studies on the native trees of sub-tropical Florida. In (A. K. M. Ghouse \& M. Yunus, Eds) Research Trends in Plant Anatomy-K. A. Chowdhury Commemoration Volume. New Delhi: Tata McGraw-Hill.

Unger, F. (1859). Der versteinerte Wald bei Cairo und einige andere Lager verkieselten Holzes in Ägypten. Sitzungberichte der Mathematische-Naturwissenschaftlichen Classe der Kaiserlichen Akademie der Wissenschaften (Wein) 33, 209-233.

Unger, F. (1866). Notiz uber fossile Hölzer aus Abyssinien. Sitzungberichte der MathematischeNaturwissenschaftlichen Classe der Kaiserlichen Akademie der Wissenschaften (Wein) 54, 289-297.

Vondra, C. F. (1967). Stratigraphy of the Upper Eocene and Oligocene deposits in the Fayum Depression, Egypt. Geological Society of America Abstracts with Programs, p. 229.

Vondra, C. F. (1974). Upper Eocene transitional and near-shore marine Qasr el Sagha Formation, Fayum Depression, Egypt. Annals of the Geological Survey of Egrpt 4, 79-94.

Whybrow, P. J. \& McClure, H. A. (1980). Fossil mangrove roots and paleoenvironments of the Miocene of the eastern Arabian Peninsula. Palaeogeography, Palaeoclimatology, Palaeoecology 32, 213-225.

Wing, S. L. (1980). Fossil floras and plant-bearing beds of the central Bighorn Basin. In (P. D. Gingerich, Ed.) Early Cenozoic Paleontology and Stratigraphy of the Bighorn Basin, Wyoming, 1880-1980. University of Michigan Papers on Paleontology 24, pp. 119-126.

Zittel, K. A. (1883). Beiträge zur Geologie und Paläontologie der Libyschen Wüste und der angrenzenden Gebeite von Ägypten, 1-1, Geologischer Theil. Paläontolographica 30, 1-147.

Zwell, M. \& Conroy, G. C. (1973). Multivariate analysis of the forelimb of Dryopithecus africanus Nature 244, 373-375. 